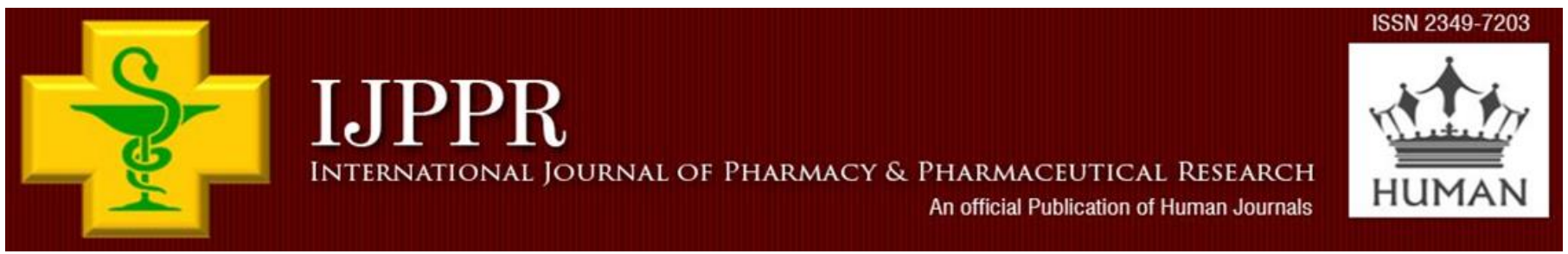

Human Journals

Research Article

March 2020 Vol.:17, Issue:4

(C) All rights are reserved by Antariksh Kumar Arya et al.

\title{
Pharmacological Activity of Dried Kernels of Juglans regia on Ovotoxicity Induced Post-Menopausal Complications in Female Rats
}

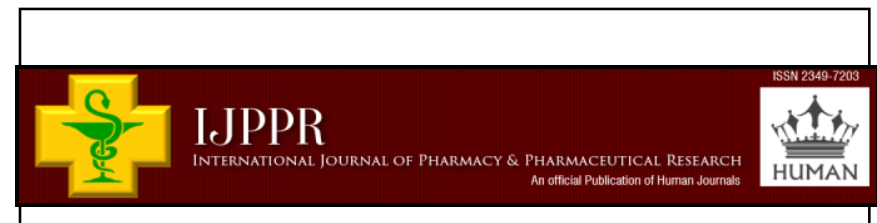

Antariksh Kumar Arya*, Mamta F. Singh, Mahak Arora

Sardar Bhagwan Singh Post Graduate Institute of Biomedical Science and Research, Balawala, Dehradun, Uttarakhand.

Submission: 22 February 2020

Accepted: $\quad 29$ February 2020

Published: $\quad 30$ March 2020
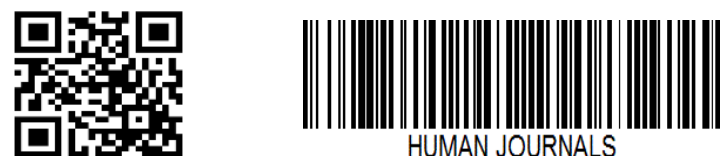

www.ijppr.humanjournals.com
Keywords: Acetylcholinesterase, estrogen, menopause, Juglans regia, 4-vinyl cyclohexane diepoxide.

\section{ABSTRACT}

The main objective of this study to analyse the effects of paste of dried kernels of Juglans regia on ovotoxicity induced (VCD80 mg/kg i.p. 5 times/week for 15 days) postmenopausal complications in female rats. Vaginal smear, behavioral studies, cardiovascular complications, osteoporosis, acetylcholinesterase and monoamine neurotransmitters (by HPLC method) were estimated before and after administration of VCD and Juglans regia. Ovaries and endometrium were isolated for the estimation of oxidative stress (LPO) and antioxidant enzyme (SOD and GSH) and for histopathological study. Results indicate that treatment of ovotoxic rats with dried kernels of $J R$ at different doses caused improvement in EPM and MWM indicating improvement in cognition and anxiety in postmenopausal rats. Treatment also decrease in serum level of cholesterol, triglyceride, VLDL, LDL, AI, calcium, magnesium, phosphorus and increase the level of HDL in ovotoxic rats. Kernels of $J R$ also improved the level of excitatory neurotransmitters and decreased the level of acetylcholinesterase in brain. It also decreased the level of oxidative stress in ovaries as indicated by decrease in LPO and by improving the level of SOD and GSH. Histopathological studies also indicate improvement in the status of ovarian follicles and endometrium. Result concludes that the paste of dried kernel of $J R$ at a dose of $400 \mathrm{mg} / \mathrm{kg}$ has the potential to restore the level of biochemical parameters, neurotransmitters, oxidative stress, minerals and can improve the complications associated with menopause without having any effect on the level of estrogen, estrous cycle and histology of ovarian follicles in postmenopausal rats. 


\section{INTRODUCTION}

Ovaries are the main source of synthesis of estrogen which has a significant role in growth, differentiation of the female reproductive system, bring out feminine characteristics, control reproductive cycle, pregnancy, immunity, influence skin, maintain bone mass and protect the cardiovascular system and brain(1). In menopause, the menstrual cycle stop permanently due to the abnormal development or depletion of ovarian follicles because the ovary does not respond to FSH, which decreases the level of estrogen and progesterone. The low level of both the hormones increases the level of FSH and LH and lead to several symptoms like hot flashes, osteoporosis, cardiovascular disease, libido, mood swing, vaginal dryness and thickening of the vaginal mucosa, urinary incontinence etc.(2, 3). Menopause occurs naturally at the age of 45-55year. However, it may be caused by smoking, surgery, and chemotherapy(4). Initially, there is perimenopause phase for a period of 5-6 years which is characterized by symptom like irregular periods, hot flushes, sleep disturbance, etc. After a year the menopausal women termed as postmenopausal $(3,5)$.

The vasomotor symptoms like hot flushes and night sweats are occurs due to dysregulation of the thermostat center in the hypothalamus and increased level of epinephrine $(6,7)$. Low level of estrogen causes bone loss due to increased bone resorption and decrease in bone formation processes(4). In menopause, the level of RANKL (Receptor activator of nuclear factor kappaB ligand) increases which leads to increased formation of osteoclasts and osteoporosis $(8,9)$. Osteoporosis and osteopenia both cause alveolar bone loss (10). In menopausal women, the bone remodeling is effected by interleukin-6 (IL-6) activation that enhances bone resorption and osteoclast (11). At the time of menopause, the level of magnesium also decreases which effects synthesis of adrenaline, serotonin, melatonin as well as blood vessel spasm and menstrual migraine and osteoporosis (12).

The incidence of atherosclerosis in menopausal women is due to the increased level of oxidized serum LDL. Overexpression of the angiotensin receptor (AT-I R) causes endothelial dysfunction and high vasoconstriction with atherosclerosis. In postmenopausal women, the low concentration of NO (nitrous oxide) cause cardiovascular diseases by enhancing smooth muscle proliferation, inflammation and atherogenic effect in the vasculature. Free fatty acid level also increases at the time of menopause which causes postmenopausal women more susceptible to insulin resistant and metabolic syndromes; both are a risk factor for cardiovascular disease(13-15). 


\section{www.ijppr.humanjournals.com}

A low level of estrogen acts as a pro-oxidant due to the presence of catechol and promotes oxidative stress(13). In menopausal women, the synthesis of acetylcholine as well as the number of cholinergic neurons is decreased and is responsible for cognitive impairment(16). Low level of estrogen causes several neuroendocrine changes in brain and autonomic nervous system and effects many cellular and biochemical processes which effect on memory, mood, behavior, vasomotor reactivity and functions of nervous system. Deficiency of estrogen influences the development of Alzheimer's disease (AD)(17). Menopause changes sleep efficiency by vasomotor symptoms, increased development of fibromyalgia and frequency of sleep-disordered breathing. Low levels of estrogen enhance the arousals number(18).

In 1942, USA approved the use of conjugated equine estrogen (CEE) to treat the symptoms of menopause. Hormone replacement therapy (HRT) was used clinically in 1950s, when estrogen was isolated from pregnant mares urine for the treatment of menopause. Traditionally HRT corrected the growing risks associated with menopause to greater extent, but they themselves are associated with severe risks, contraindicating and adverse effects. Later more traditional alternatives were searched and role of phytoestrogen came into existence (19-21). Phytoestrogen are considered natural therapeutic alternatives to synthetic hormonal therapies, which are not associated with chronic indications and adverse effects. Phytoestrogen are structurally similar to estrogen and minimizes the menopausal symptoms. Phytoestrogen like soy isoflavones (genistein and daidzein) are reported to improve many clinical conditions like neurodegenerative, osteoporosis, depression, metabolic disorder, vasomotor symptoms of menopause(22, 23). In-plant kingdom, several plants containing phytoestrogens are used to treat menopausal symptoms. Walnut is a seed, obtained from the fruits of Juglans regia (JR) family Juglandaceae. Apart from 30 types of walnuts, only 3 varieties are used for commercial purposes that are J. regia, J nigra and J. cinerea. Traditionally walnuts are used to treat cancer of lung and liver, diabetes, asthma, cardiovascular disorder, etc $(24,25)$. Walnut is rich sources of protein, fats, minerals, vitamins, flavonoids, phenolic acid, peptic substances, and polyphenols. The kernels of $J R$ contains omega-3 and omega-6 fatty acids, juglone, glutamate, aspartate, arginine, lysine, stearic acid, palmitic acid, melatonin, Oleic acid, linoleic acid, $\alpha$-linolenic acids, etc $(26,27)$. Therefore in the present study, the paste of dried kernels of Juglans regia at different doses was evaluated for their effects in menopausal complications. 
www.ijppr.humanjournals.com

\section{MATERIAL AND METHODS}

\section{Drug and Chemical}

Dopamine hydrochlorides, DHBA (dihydroxybenzylamine) were purchased from Sigma. Estradiol, 4-vinyl cyclohexene diepoxide, L-noradrenaline hydrochloride were purchased from Sigma Aldrich. Acetylthiocholine iodide, Bovine serum albumin, citric acid (HPLC99.7\%), DTNB, Folin's phenol reagent, Glacial acetic acid (99.8\% HPLC), hydroquinone, methanol (HPLC), molybdic acid, o-phosphoric acid (85\%HPLC) from Hi-Media. Other chemicals were obtained from local sources and were of analytical grade. Diagnostic kits were used for the estimation of all biochemical parameters.

\section{Animals}

Female Wistar rats weighing between $150-200 \mathrm{~g}$ and 8 - 10 weeks of age were used for study. The rats were housed in standard cages and were allowed to have free access to food and water ad libitum under controlled room temperature $\left(24 \pm 2^{\circ} \mathrm{C}\right)$ in a 12-h light-dark cycle. The guidelines of the Committee for the Purpose of Control and Supervision of Experimental Animals (CPCSEA) of the Government of India were followed and prior permission was taken from the Institutional Animal Ethical Committee (273/PO/Re/S/2000/CPCSEA/20172018/002) for conducting the animal experimental studies.

\section{Preparation of Test Sample}

The dried fruits of Juglans regia (walnut) were purchased from the local market of Dehradun and ground to a fine paste in distilled water and sonicated for 20 minutes.

\section{Induction of ovotoxicity and Menopause}

Ovotoxicity was induced by the Accelerated Ovarian Failure (OVF) method in female rats. 4vinyl cyclohexene diepoxide (VCD) at a dose of $80 \mathrm{mg} / \mathrm{kg}$, i.p. five times per week for 15 days was injected in rats(28).

\section{Dose selection}

As indicated in the literature the toxicity studies of dried kernels of Juglans regia was already done(24). On the basis of previous work, dose levels of $100 \mathrm{mg} / \mathrm{kg}, 200 \mathrm{mg} / \mathrm{kg}$ and 400 $\mathrm{mg} / \mathrm{kg}$ p.o. were selected for further studies. 


\section{Treatment protocol}

VCD treated animals (ovotoxic animal) were divided into five groups, each having six animals and one group of normal animals (untreated group 1) was included in the study. Animal in group 1 and in group 2 (ovotoxic animals) received normal saline at a dose of 1 $\mathrm{ml} / \mathrm{kg} / \mathrm{p}$.o. The ovotoxic animals in group 3 received $100 \mathrm{mg} / \mathrm{kg}$, p.o. of paste of dried kernels of $J R$, group 4 received $200 \mathrm{mg} / \mathrm{kg}$, p.o. and group 5 received $400 \mathrm{mg} / \mathrm{kg}$. p.o. of paste of dried kernels of $J R$ and group 6 animals received $60 \mathrm{mg} / \mathrm{kg}$ estrogen. The treatment was given for a period of 45 days.

Vaginal smears were prepared before and after induction of ovotoxicity and at different stages of the treatment period. Behavioral studies using animal models were carried out before and after the induction of ovotoxicity and after the treatment of 60 days. After the physical studies, all the animals were fasted overnight, blood was withdrawn from the retroorbital plexus and centrifuged at $2500 \mathrm{rpm}$ at $3^{\circ} \mathrm{C}$ for $15 \mathrm{~min}$ using cooling centrifuge. Serum was used for the estimation of estrogen, cholesterol, HDL-cholesterol, total protein, LDH, calcium, magnesium, and phosphates. Estrogen level was evaluated before and after the induction of ovotoxicity and after the treatment period. Animals were sacrificed by euthanasia by phenobarbital $150 \mathrm{mg} / \mathrm{kg}$, i.p. Ovaries and brains were excised immediately, washed with ice cold saline, weighed and homogenized in phosphate buffer $(50 \mathrm{mM}, \mathrm{pH} 7.4)$ to prepare a $10 \%(\mathrm{w} / \mathrm{v})$ solution. The homogenate was centrifuged at $7000 \mathrm{Xg}$ for $10 \mathrm{~min}$ at $40^{\circ} \mathrm{C}$ and the supernatant was used for the study of the neurotransmitter levels while supernatant from ovaries was used for the study of oxidative stress parameters in normal and treated rats. Endometrial thickness and histopathology of ovaries of animals from each treatment group was done after the treatment period.

\section{Elevated plus-maze model for cognition and behavior}

The EPM consisted of four arms, forming plus shape and uplifted $50 \mathrm{~cm}$ from the ground. All the arm were attached by a neutral field $(5 \times 5 \mathrm{~cm})$ in which two opposing arm were open $(25 \times 5 \mathrm{~cm})$ arm have a $0.5 \mathrm{~cm}$ wall to reduce the falling number and the other two closed $(25 \times 5 \times 16 \mathrm{~cm})$ arm were closed by black wall that had a height of $16 \mathrm{~cm}$. On the first day $\left(7^{\text {th }}\right.$ day of the treatment), after the oral administration of vehicle or test drug individually animals were placed at the end of open arms for 2 minutes and the time taken by animals to move from open arm to closed arm (transfer latency) is noted. Animals were allowed to explore the 
plus-maze for $2 \mathrm{~min}$. Retention memory of the learning task was analyzed $24 \mathrm{hrs}$ after the first-day trial. On the first day, the measured transfer latency of plus-maze served as an index of learning and acquisition, whereas transfer latency on $2^{\text {nd }}$ day served as an index of retrieval and memory(29).

\section{Morris Water Maze model for cognition and behavior}

Morris water maze consisted of a small circular pool had $50 \mathrm{~cm}$ diameter, $30 \mathrm{~cm}$ height and filled to a depth of $22-23 \mathrm{~cm}$ with opaque water maintained at $30-35{ }^{\circ} \mathrm{C}$ for rats. The water was made opaque with the help of non-toxic substances like milk. By fixing the two threads at the right angle to each other on the pool rim, the tank was divided into four equal quadrants. A white-painted platform of $10 \mathrm{~cm}$ diameter was placed inside the target quadrants of this pool $1 \mathrm{~cm}$ lower to the surface of water. Every animal was subjected to successive training of 5 minutes each day. The animal was placed facing the wall of the pool with a drop in the water between quadrants and $120 \mathrm{sec}$ provided to the animal for locating invisible platform and 20 second to stay on the platform, the drop location was changed for each trial. If the animal was unable to find the platform within $120 \mathrm{sec}$, it was guided onto the platform and allowed for $20 \mathrm{sec}$ to remain there. Day 4, escape latency time (ELT) to locate the hidden platform in the water maze was noted as an index of acquisition or learning. Animal was subjected to training trial for 4 successive days; the starting position was changed with each exposure. On the fifth day, each animal was allowed to explore the pool for 120 seconds and this platform removed out from the pool. The average of the total time spent in all four quadrants by the animal was calculated and its termed as index of retrieval or memory(30).

\section{Vaginal Smear for morphological examination}

During the treatment protocol for examination of vaginal smear, every morning between 8:00 - 9:00 AM the vaginal sample was collected. The tip was inserted into the rat's vagina. The bulb was gently depressed to expel a quarter to half of the volume of normal saline $(\sim 25-50$ $\mu l)$ at the opening of the vaginal canal. The liquid spontaneously aspirated into the canal without tip insertion. The fluid from the vaginal canal was withdrawn back into the tip. The previous steps were repeated 4-5 times using the same tip, bulb, and fluid to obtain enough cells in a single sample. The fluid was placed on a glass slide and the smears were allowed to completely dry at room temperature. The dry slide was placed in a Coplin jar that contained the crystal violet stain for 1 minute. It was removed to a second Coplin jar containing 
distilled water for 1 minute. The excess distilled water was removed from the boundaries of the slide with a light-duty tissue wiper, avoiding contact with the stained smear. Approximately $15 \mu 1$ of glycerol was pipetted on top of the smear and coverslip was placed. Slide material was observed under a light microscope with 10 and $40 \mathrm{x}$ objective lenses(31).

\section{Estrogen}

The estimation of estrogen was carried out by from serum using an ELISA kit (32).

\section{Estimation of Cardiovascular risk factors (lipid profile)}

Serum cholesterol, triglyceride, high density cholesterol (HDL-cholesterol) level were estimated byCHOD-PAP method with LCF;(33), Enzymatic Colorimetric Method or GPO(34), and Phosphotungstic Acid Method (35), respectively using ERBA diagnostic kits. The concentration of VLDL, LDL and atherogenic index was obtained by using formula.

$$
\begin{gathered}
\mathrm{LDL}=\mathrm{TG} / 5 \\
\mathrm{VLDL}=\mathrm{TC}-\mathrm{HDL} \\
\text { Atherogenic Index }=\mathrm{TC}-\mathrm{HDL} / \mathrm{HDL} .
\end{gathered}
$$

\section{Marker enzyme assay}

Lactate dehydrogenase was estimated by UV-kinetic method (36) using ERBA diagnostic kit.

\section{Bone Markers}

Total protein and calcium levels were estimated according to the biuret method(37) and OCPC endpoint method (Theodore, 1972) respectively using commercial ERBA kits. Magnesium(38) and inorganic phosphate(39)were also determined by using diagnostic kits.

\section{Estimation of biogenic amines (Noradrenaline, serotonin and dopamine) by HPLC method}

Brain was quickly fixated and frozen in 2-methyl butane kept at $-40^{\circ} \mathrm{C}$ over dry ice to avoid degradation of the biogenic amines and metabolites. The brain tissue (100 $\mathrm{mg}$ ) was homogenized (30s) in a $4 \mathrm{ml}$ buffer at $4^{\circ} \mathrm{C}$ using a tissue homogenizer. The $\mathrm{pH}$ of the mixture was measured and transferred into 1-ml Eppendorf tubes and promptly centrifuged at 
$14,000 \mathrm{rpm}$ and $4^{\circ} \mathrm{C}$ for 15 minutes. The time of centrifugation was kept 20 minutes at 10,000 $\mathrm{rpm}$, and the samples were maintained at $4^{\circ} \mathrm{C}$. The supernatant was then filtrated through a $0.2 \mathrm{mMillipore}$ filter. Further elimination of proteins was accomplished with a spin $10-\mathrm{kDa}$ protein cut-off filter. The flow rate was kept $0.05 \mathrm{ml} / \mathrm{min}$ and column temperature set at $35^{\circ} \mathrm{C}$. The standard solutions contained noradrenaline (NA), adrenaline (Adr), dihydroxybenzylamine(DHBA), dopamine (DA), and serotonin (5-HT) in phosphatecitric buffer at a concentration of $10 \mathrm{ng} / \mathrm{ml}$ respectively. The optimal chromatographic conditions were applied for the complete validation process. Four standard solutions in running buffer containing, NA (2, 3, 4, 6 and $10 \mathrm{ng} / \mathrm{ml})$, Adr (2, 3, 4, 6 and $10 \mathrm{ng} / \mathrm{ml})$, DHBA $(2,3,4,6$ and $10 \mathrm{ng} / \mathrm{ml})$, DA (2, 3, 4, 6 and $10 \mathrm{ng} / \mathrm{ml}), 5-\mathrm{HT}((2,3,4,6$ and $10 \mathrm{ng} / \mathrm{ml})$ were prepared for calibration curves. The calibration standard curve for each molecule was established based on the concentrations [nM] vs. peak area [nAs]. Linear curve fit was used and correlation coefficiency (r2) was found to be higher than 0.995. The internal standard (DHBA) was chosen based on structural similarity with the molecules of interest, respectively, for catecholamines and serotonergic molecules. The run-to-run variability was eliminated giving more precise results (40).

\section{Estimation of Acetylcholinesterase}

Acetylcholinesterase was determined by Ellman G. L. et.al, 1961 method using brain tissue homogenate. $0.4 \mathrm{ml}$ of brain tissue homogenate was added to a cuvette containing $2.6 \mathrm{ml}$ phosphate buffer $(0.1 \mathrm{M}, \mathrm{pH} 8)$ and $100 \mu \mathrm{l}$ of DTNB was added to it. The contents of cuvette were mixed thoroughly by bubbling air and absorbance was measured at $412 \mathrm{~nm}$ in a spectrophotometer. When absorbance reaches a stable value, it was recorded as the basal reading. $20 \mu 1$ of substrate i.e., acetylthiocholine was added and changes in absorbance were recorded(41).

\section{Estimation of lipid peroxidation and antioxidant enzymes (superoxide dismutase and reduced glutathione) from rats ovaries}

Estimation of lipid peroxidation was done from the tissue supernatant of by the method of Slater and Sawer, 1971(42). Superoxide dismutase and reduced glutathione were estimated by the method of Mishra et. al 1972 and Moron et. al, 1979 respectively using supernatant from ovaries(43)(44). 
www.ijppr.humanjournals.com

\section{Histopathology}

The ovaries were dissected and rapidly fixed in $10 \%$ buffered formalin for 24 to 48 hours. After fixation, each ovarian tissue was routinely processed and was embedded in paraffin and paraffin blocks were prepared. With the help of microtone, 5-mm-thick sections were cut from paraffin-embedded tissue. After deparaffinization and rehydration, sections were stained with hematoxylin and eosin and coverslip was placed upon the slide and studied under a microscope (45).

\section{Determination of Endometrial thickness of rats uterus}

The uteri were isolated from sacrificed rats and the adhering fat was trimmed and removed off. The sample was then being fixed in $10 \%$ formalin for 24 hours at room temperature. The tissue sample was dehydrated in graded methanol, cleared by xylene and then embedded in paraffin to prepare paraffin blocks. Then sections of $4 \mu \mathrm{m}$ thickness were cut by microtome, mounted over the glass slides, dewaxed and rehydrated with distilled water. It was then stained with hematoxylin and eosin and endometrial thickness was measured under a light microscope(46).

\section{Statistical Analysis}

The statistical analysis was carried out using Graph Pad Prism 8.0 software. All values were presented as Mean \pm SEM. Multiple comparisons between different groups were performed using Analysis of Variance (ANOVA) followed by the Donetts Multiple Comparison Test. The difference level at $p<0.05$ was considered statistically significant.

\section{RESULT}

\section{Effect of paste of dried kernels of Juglans regia on Transfer latency in ovotoxicity induced cognitive impairment in female rats using the Elevated Plus Maze apparatus.}

Figure 1 shows that the administration of VCD caused a gradual increase in transfer latency (TL) in postmenopausal rats on day $15^{\text {th }}(56.5 \pm 3.01)$ as compared to day $1(20.25 \pm 5.17)$. Treatment of postmenopausal rats with a paste of dried kernel of $J R$ at a dose of $400 \mathrm{mg} / \mathrm{kg}$ for a period of 45 days caused a significant decrease $(\mathrm{P}<0.001)$ in $\mathrm{TL}$. The results were mild to moderately significant $(\mathrm{P}<0.05)$ at the dose level of $200 \mathrm{mg} / \mathrm{kg}$ of paste of dried kernel of $J R$. Estradiol administered at a dose of $60 \mathrm{mg} / \mathrm{kg}$ for 45 days also showed significant 
$(\mathrm{P}<0.001)$ decrease in TL time on day 60(12.75 2.06$)$ when compared to day $15(62.75 \pm 5.5)$ of the study.

\section{Effect of paste of dried kernels of Juglans regia on Escape latency in ovotoxicity induced cognitive impairment in female rats using the Morrish Water Maze apparatus.}

The effects of paste of dried kernels on EL are summarized in figure 2. Administration of VCD showed cognitive impairment by increasing escape latency in ovotoxic female rats on day 15(53.5 \pm 3.28$)$. Treatment of postmenopausal rats with a paste of dried kernel of $J R$ at a dose of $400 \mathrm{mg} / \mathrm{kg}$ for a period of 45 days caused a significant decrease $(\mathrm{P}<0.001)$ in EL as compared to day 15 of the respective groups. Paste of dried kernels of $J R$ at a dose of 200 $\mathrm{mg} / \mathrm{kg}$ also caused a decrease in EL in postmenopausal rats but the results were only moderately $(\mathrm{P}<0.01)$ significant. The group of ovotoxic animals receiving estradiol for 45 days also showed the most significant $(\mathrm{P}<0.001)$ decrease in EL time on day $60(12.25 \pm 1.25)$ when compared to day $15(61.25 \pm 8.73)$.

Effect of paste of dried kernels of Juglans regia on vaginal cytology in ovotoxicity induced postmenopausal complication in rats.

Figure 3 shows different phases of the estrus cycle on 0 days of the study, after induction of menopause and after treatment with different doses of paste of dried fruits. Most animals of normal group were in metestrus phase. After 15 days of VCD induction, all groups were found to be in the diestrus phase, except normal group animals that were either in the estrus or proestrus phase. After the treatment period of 45 days, the female rats of normal, control groups and group treated with paste of dried kernel of $J$ Rat a dose of $100 \mathrm{mg} / \mathrm{kg}$ were found to be in metestrus phase. Animals treated with $200 \mathrm{mg} / \mathrm{kg}, 400 \mathrm{mg} / \mathrm{kg}$ of dried paste and estrogen-treated group were found in proestrus phase, diestrus phase, estrus phases respectively.

Effect of paste of dried kernels of Juglans regia on serum estrogen level in ovotoxicity induced postmenopausal complication in rats.

Result summarized in figure 4 shows that the effect of VCD on estrogen levels in female rats. The administration of VCD for a period of 15 days caused significant $(\mathrm{P}<0.001)$ decrease (31.48 \pm 2.99$)$ in estrogen level as compared to day $1(96.87 \pm 2.77)$. Treatment of ovotoxic rats by the paste of dried kernels of $J$ Rat a dose of $400 \mathrm{mg} / \mathrm{kg}, 200 \mathrm{mg} / \mathrm{kg}$, and $100 \mathrm{mg} / \mathrm{kg}$ for 60 
days does not affect the level of estrogen in serum. Whereas a significant $(\mathrm{P}<0.001)$ increase in serum estrogen levels was observed in the $6^{\text {th }}$ group which was treated with estrogen $60 \mathrm{mg} / \mathrm{kg}$ at day $60(79.19 \pm 6.87)$.

\section{Effect of paste of dried kernels of Juglans regia on cardiovascular parameters (cholesterol, triglyceride, LDL, VLDL, HDL and atherogenic index) in ovotoxicity induced postmenopausal complication in rats.}

Result in table 1 indicates that the level of cholesterol and triglyceride were increased significantly after the administration of VCD in all groups of animals. It indicated abnormalities in lipid metabolism associated with postmenopausal complications. The level of cholesterol and triglycerides increased from $77.34 \pm 3.73$ and $52.36 \pm 1.79$ to $125.7 \pm 2.90$ and $92.49 \pm 0.86$ respectively after treatment with VCD. The paste of dried kernels of $J$ Rat a dose of $400 \mathrm{mg} / \mathrm{kg}$ for 60 days caused significant $(\mathrm{P}<0.001)$ decrease in serum cholesterol $(67.34 \pm 1.7)$ and triglyceride $(52.07 \pm 0.86)$ level in ovotoxic rats. Treatment of ovotoxic rats with a dose of $200 \mathrm{mg} / \mathrm{kg}$, paste of $J R$ also caused moderately significant $(\mathrm{P}<0.01)$ decrease in serum cholesterol $(77.66 \pm 3.61)$ and triglyceride $(57.58 \pm 0.5)$ levels in ovotoxic animals on day 60. Estrogen therapy also normalized the cholesterol and TG level significantly $(\mathrm{P}<0.001)$ in ovotoxic rats.

Administration of VCD for 15 days caused a significant decrease $(\mathrm{P}<0.001)$ in serum HDL levels in ovotoxic postmenopausal rats. Paste of dried kernels of $J$ Rat a dose of $400 \mathrm{mg} / \mathrm{kg}$ has significant $(\mathrm{P}<0.001)$ effects on serum HDL level in ovotoxic menopausal rats and caused increase in serum HDL level $(32.13 \pm 1.22)$ on day 60 as compared to day $15(18.23 \pm 0.81)$. A slight increase in the level of HDL was observed in rats treated with $J R 200 \mathrm{mg} / \mathrm{kg}$ dose (26.63 \pm 0.78$)$. Estrogen therapy had significant effect of serum HDL level and normalized the HDL level from $18.51 \pm 0.33$ to $48.47 \pm 0.47$ in ovotoxic rats on day 60 shows in table 1 . Resultsin table 1also indicates that the paste of dried kernels of $J$ Rat a dose of $400 \mathrm{mg} / \mathrm{kg}$ for 60 days caused significant decrease in the level of serum VLDL and LDL from 15.71 \pm 0.34 and $77.51 \pm 2.52$ to $10.41 \pm 0.17$ and $24.8 \pm 53$ respectively after 45 days of treatment. Atherogenic index was also increased significantly in female rats after induction of menopause and the level of AI was increased from $1.39 \pm 0.18$ to $5.935 \pm 0.37$ in postmenopausal rats. Table 1 shows a highly significant $(\mathrm{P}<0.001)$ decrease in the level of AI in the group administered with $J R 400 \mathrm{mg} / \mathrm{kg}(1.1 \pm 0.07)$. Estrogen therapy also normalized the AI level from $4.18 \pm 0.27$ to $0.318 \pm 0.01$. 
www.ijppr.humanjournals.com

Effect of paste of dried kernels of Juglans regia on serum calcium, magnesium and phosphorus level in ovotoxicity induced postmenopausal complications in female rats.

The effect of different doses of a paste of dried kernel of $J R$ was studied for estimation of mineral content in serum that included analyzing the level of calcium, magnesium, and phosphorus and gives us the measure of osteoporosis in postmenopausal rats. Table 2 shows that the administration of VCD caused a significant $(\mathrm{P}<0.001)$ increase in serum calcium, magnesium and phosphorus level in all groups of female rats indicating bone resorption and osteoporosis. The level of calcium was increased on the $15^{\text {th }}$ day of VCD administration from $7.2 \pm 0.63$ to $15.15 \pm 0.69$. Administration of paste of dried kernel of $J R$ at a dose of $400 \mathrm{mg} / \mathrm{kg}$, $200 \mathrm{mg} / \mathrm{kg}$ dose levels for 45 days, significantly $(\mathrm{P}<0.001)$ decreased the level of calcium $(7.13 \pm 0.64$ and $9.1 \pm 0.34$ respectively) in postmenopausal rats. Estrogen treatment has shown the most significant $(\mathrm{P}<0.001)$ reduction $(6.97 \pm 0.28)$ in serum calcium levels in postmenopausal rats. Paste of dried kernels of $J R$ at a dose of $400 \mathrm{mg} / \mathrm{kg}$ dose for 45 days also decreased the level of magnesium and phosphorus in serum from to $4.51 \pm 0.33,15.26 \pm 0.63$ to $1.893 \pm 0.029$ and $6.37 \pm 0.47$ respectively in postmenopausal rats. The paste of dried kernel of $J R$ at doses of $200 \mathrm{mg} / \mathrm{kg}$ dose showed less significant results in postmenopausal rats. The result of $J R$ at $100 \mathrm{mg} / \mathrm{kg}$ dose showed non-significant reduced in the level of magnesium and phosphorus in serum. The estrogen-treated group has shown the most significant $(\mathrm{P}<0.001)$ decrease in the level of magnesium and phosphorus in serum in rats.

Effect of paste of dried kernels of Juglans regia on brain monoamines (noradrenaline, serotonin and dopamine) level by HPLC in ovotoxicity induced postmenopausal complications in female rats.

The levels of excitatory monoamines were calculated using HPLC against a standard solution that was estimated from the brain homogenate levels of ovotoxic female rats and normal female rats. The figure 5 shows results of HPLC showing Retention time, area of the peak and height of the peak for each solution run in HPLC in which (a) represents the levels of excitatory monoamines for standard solution prepared at a concentration of $10 \mathrm{ng} / \mathrm{ml}$, while (b) represents levels of excitatory monoamines in the brain homogenates of a normal animal which was found to have concentration of $2.55 \mathrm{ng} / \mathrm{ml}$ with peak area of $478057 \mu \mathrm{v}^{*} \mathrm{sec}$ calculated against standard of concentration $10 \mathrm{ng} / \mathrm{ml}$ with the peak area of $1874538 \mu \mathrm{v}^{*} \mathrm{sec}$. similarly, (c) represents levels of excitatory monoamines in the brain homogenates of positive control animal which was found to have concentration of $0.26 \mathrm{ng} / \mathrm{ml}$ with peak area of 48768 
$\mu \mathrm{V}^{*} \mathrm{sec}$ calculated against standard of concentration $10 \mathrm{ng} / \mathrm{ml}$ with the peak area of 1874538 $\mu v^{*} \sec$ the (d) shows levels of excitatory monoamines in the brain homogenates of animal treated with paste of dried kernels of $J R$ at a dose of $400 \mathrm{mg} / \mathrm{kg}$ which was found to have concentration of $1.46 \mathrm{ng} / \mathrm{ml}$ with peak area of $274383 \mu \mathrm{v}^{*} \mathrm{sec}$ calculated against standard of concentration $10 \mathrm{ng} / \mathrm{ml}$ with the peak area of $1874538 \mu \mathrm{v}^{*} \mathrm{sec}$.

Effect of paste of dried kernels of Juglans regia on brain acetylcholinesterase level in ovotoxicity induced postmenopausal complications in female rats.

The effect of menopause on the brain AchE level as summarized in figure 6 . The result of the study shows that the level of AchE was significantly $(\mathrm{P}<0.001)$ increased $(36.97 \pm 1.79)$ in VCD treated ovotoic rats as compared to normal female rats (17.98 \pm 0.66$)$ indicating decreased in the level of Ach and cognitive impairement. The paste of dried kernel of $J R$ at a dose of $400 \mathrm{mg} / \mathrm{kg}$ administered for 45 days to the ovotoxic rats caused significant $(\mathrm{P}<0.001)$ reduced (20.33 \pm 1.32$)$ the level of AchE as compared to control group. Paste of dried kernel of $J R$ at a dose of $200 \mathrm{mg} / \mathrm{kg}$ caused moderate decrease $(23.11 \pm 0.91)$ in the brain level of AchE in ovotoxic rats whereas at a dose of $100 \mathrm{mg} / \mathrm{kg}$ the paste does not have any effect on AchE level. Estrogen therapy for 45 days caused most significant improvement $(16.51 \pm 0.45)$ in the level of AchE and memory of ovotoxic rats.

Effect of paste of dried kernels of Juglans regia on brain oxidant (lipid peroxidation)antioxidant status (superoxide dismutase and glutathione peroxidase) in ovotoxicity induced postmenopausal complications in female rats.

Results in table 3 indicates that VCD administration for 15 days to female rats caused significant $(\mathrm{P}<0.001)$ increase $(138 \pm 11.45)$ in the level of lipid peroxidation (LPO) in the ovaries of female rats. Administration of paste of dried kernel of $J R$ at a dose of $400 \mathrm{mg} / \mathrm{kg}$ for 45 days restored the levels of LPO $(59.07 \pm 1.70)$ in postmenopausal rats. At a dose of 200 $\mathrm{mg} / \mathrm{kg}$, the paste of kernels also caused moderately significant $(\mathrm{P}<0.01)$ decrease in the LPO level in ovaries of postmenopausal rats. Estrogen therapy given for 45 days also caused significant $(\mathrm{P}<0.001)$ decrease $(46.11 \pm 1.68)$ in the level of LPO in postmenopausal rats.

Table 3 also shows that the administration of VCD caused significant $(\mathrm{P}<0.001)$ decrease in the level of superoxide dismutase (SOD) $(53.68 \pm 1.79)$ and reduced glutathione $(54.12 \pm 1.73)$ as compared to normal group. Administration of paste of dried kernel of JRto the ovotoxic rats at $400 \mathrm{mg} / \mathrm{kg}$ dose caused significant $(\mathrm{P}<0.001)$ increase in SOD $(90.88 \pm 1.88)$ and GSH 
(120.8 \pm 3.53$)$ level in postmenopausal rats. Estrogen therapy restored the level of SOD and GSH to normal in ovotoxic postmenopausal rats.

\section{Effect of paste of dried kernels of Juglans regia on histology of ovarian follicles in VCD induced postmenopausal complications in female rats.}

Results in figure 7 show that the ovarian section of a normal group of animal ovaries having no sign of corpus luteum, unremarkable ovarian tissues and an appropriate number of primordial follicles. Groups of animal treated with a paste of dried kernel of $J R$ at a dose of $400 \mathrm{mg} / \mathrm{kg}$ shows mild to moderate decrease in number of primordial follicles and increase corpus luteum in minute amount. VCD induced group and group which treated with a paste of dried kernel $J R$ at a dose of $200 \mathrm{mg} / \mathrm{kg}$ shows markedly reduces the number of primordial follicles and increased corpus luteum. Estrogen at a dose of $60 \mathrm{mg} / \mathrm{kg}$ to a group of animal shows, no sign of corpus luteum and a sufficient number of ovarian follicles with unremarkable ovarian tissue.

\section{Effect of paste of dried kernels of Juglans regia on uterus and endometrial thickness in VCD induced postmenopausal complications in female rats.}

The endometrium section of the normal group of animals having an unremarkable endometrial gland with stroma. The group of animals treated with a paste of dried kernel of $J R$ at a dose of $400 \mathrm{mg} / \mathrm{kg}$ shows mild simple hyperplasia without atypia. Groups treated with $\mathrm{VCD}$, paste of dried kernel of $J R$ at a dose of $200 \mathrm{mg} / \mathrm{kg}$ show simple hyperplasia without atypia. Estrogen at a dose of $60 \mathrm{mg} / \mathrm{kg}$ to a group of animal shows, unremarkable endometrial gland with stroma which shows in figure 8.

\section{DISCUSSION}

In the present study "Modulatory effect of paste of dried kernels of Juglans regia on ovotoxicity induced postmenopausal complication in female rats" the effect of the paste of dried kernel of Juglans regia $(J R)$ at different dose levels were evaluated for their effects in postmenopausal complications in female rats. VCD is an ovotoxic chemical, used for induction of ovotoxicity and menopause in experimental animals. It acts by gradual degeneration of primary follicles and thereby induces menopause similar to the natural menopause in human(47). Results of the study reveals that VCD caused significant destruction of ovarian follicles as indicated by cytology of vaginal smears, decrease in serum 
estrogen level and histology of ovaries. VCD caused a gradual decline in the no. of oocytes leading to decrease in the synthesis of estrogen. The process of decline in the serum estrogen level in rats was gradual and was similar to natural menopause in humans. Treatment of ovotoxic animals with the paste of dried kernel of JRat higher dose level for a long period caused significant improvement in the memory and behavior in postmenopausal rats which is indicated by decrease in escape latency and transfer latency. The phytoconstituents present in $J R$ does not have any effects on estrogen synthesis but only binds with estrogen receptor and produces estrogen-like effects. Studies from previous literature indicates that increased level of TG and cholesterol is responsible for increasing the chances of cardiovascular diseases in postmenopausal women. HDL-C is an independent risk factor for several coronary heart diseases. In postmenopausal rats, the low level of estrogen and high level of FSH exert severe effect on lipid metabolism and lipoprotein level. It is linked with an increasing LDL, VLDL and a decrease in HDL-C level (48) and (49). In the present study, the TG, cholesterol, LDL and VLDL levels in the serum of postmenopausal rats increased by 2-20\% whereas the level of HDL was significantly decreased indicating disturbances in serum lipoprotein level. A survey of previous literature indicates that decreased level of estrogen in menopausal women is responsible for disturbances in serum lipoprotein level. The paste of dried kernels of $J R$ at $200 \mathrm{mg} / \mathrm{kg}$ moderately improved lipid profile. However, the paste of dried kernels at a dose of $400 \mathrm{mg} / \mathrm{kg}$ for 45 days caused most significant decrease in the level of serum cholesterol, TG, LDL and VLDL as well as increased serum HDL level in postmenopausal rats. The results may be contributed to a high level of omega-3, 6, 7 fatty acids and phytoestrogens present in dried paste of $J R$ and may be responsible for improvinglipid metabolism in postmenopausal rats. The kernels of $J R$ also decreased the atherogenic index in rats indicating protection from cardiovascular complications.

Some studies suggest that phytoestrogens causes activation of nuclear factor erythroid 2related factor 2-keap 1 signalling leading to induction of antioxidant electrophile response element (ARE/EpRE)-mediated gene expression which is responsible for the beneficial effects of phytoestrogens(50). EpRE mediated induction of gene expression increases cellular defense against the toxicity of ROS electrophiles and other health related problems. Activation of this pathway by phytoestrogen may be responsible for protection against cardiovascular disease. Phytoestrogen are known to modulate metabolism of lipoproteins due to estrogenic activity. They also reduces the oxidation of lipids. By increasing the secretion of bile acids in faces, increasing cholesterol secretion in liver and by changing the rate of bile 
acid secretion, phytoestrogens control cholesterol secretion. Phytoestrogens also inhibits platelet aggregation and coagulation process(51). Phytoestrogens causes improvement of lipid concentration in plasma, reduces the incidences of atherosclerosis, removes LDL from serum and also removes LDL from hepatocytes(52).

As we know that estrogen is responsible for maintaining bone mass by adjusting the rate of bone formation and resorption. Estrogen inhibits apoptosis and increases the survival of oestrocytes. In postmenopausal women, low level of estrogen is responsible for bone loss due to decreased formation of osteoblast. In postmenopausal female, lack of estrogen results in increased bone resorption. This condition results in an increased amount of calcium in serum and low level of calcium in bones causing in higher risk of osteoporosis, bone features and other bone deformities $(11,12)$. In the present study, VCD caused an increase in serum calcium level indicating bone calcium level. Treatment of the ovotoxic animals with the paste of dried kernel of $J R$ at a dose of $400 \mathrm{mg} / \mathrm{kg}$, p.o. was very effective in maintaining bone metabolism in postmenopausal rats. It may be assumed that the phytoestrogen in the paste of dried kernels of $J R$ stored bone calcium level. As we know that large number of ER present on the osteoblast, may be responsible for the effect. Phytoestrogens bind the ER and stimulates the production of osteoblast which then prevents bone resorption. Some studies also indicates that phytoestrogen prevents urinary calcium excretion, increases calcium absorption, stimulates the production of IGF-1, which enhances osteoblast activity and stimulates bone formation(53) and (54).

Estimation of magnesium and phosphorus is important as both of these minerals are required for maintaining bone density. In menopausal women deficiency of estrogen leads to disturbances in calcium, phosphate and magnesium homeostasis by affecting the regulation at the level of bone, kidney and intestine. Serum magnesium level is inversely proportional to the serum estrogen levels and its absorption is also governed by estrogen. So, the postmenopausal women usually have enhanced serum magnesium levels indicating low bone density. The level of serum inorganic phosphorus is also increased in the postmenopausal women resulting in hyperphosphatemia which indicates excessive bone resorption and lower bone density. In the present study, the paste of dried kernels of $J R$ was able to attenuate the elevated serum magnesium and phosphorus in postmenopausal rats.

The result of the present study shows that VCD caused a significant decrease in the level of brain monoamine (noradrenaline, serotonin, and dopamine) in rats as indicated by the small 
area under curve in HPLC. The kernels of $J R$ administered for 45 days significantly increased the level of monoamines in the brain (indicated by large area under curve in HPLC). Studies conducted in past also indicates that estrogen after binding to $\operatorname{Er} \beta \mathrm{R}$ increase and maintains the level of Ach, noradrenaline, serotonin, and dopamine in the brain, contributing to memory, mood, behavior and anxiety. Estrogen also enhances the synthesis as well as uptake of serotonin and noradrenaline in the brain. Phytoestrogens resembles with $17 \beta$ estradiol and also have the ability to bind to the estrogen receptors. Based upon the results, it can be assumed that phytoestrogens of $J R$ binds to $\operatorname{Er} \beta \mathrm{R}$ and increases the level of monoamines in the brain of postmenopausal rats and decreases the complications of menopause like hot flushes, anxiety and mood changes.

In menopausal women, a low level of estrogen causes an imbalance between hormones and leads to cognitive disturbances. Estrogen $\mathrm{R}(\mathrm{ER}-\beta)$ present in the hippocampus, regulates learning and memory by increasing biosynthesis of neurotransmitters in the brain. Lack of estrogen at the time of menopause causes low level of neurotransmitters which may impair memory and learning functions. In menopausal women, high level of acetylcholinesterase (AchE) is responsible for decreasing the level of acetylcholine. In this study, the level of acetylcholinesterase was significantly high in postmenopausal rats. Administration of $J R$ at a dose of $400 \mathrm{mg} / \mathrm{kg}$ to the ovotoxic rats leads to decrease in the level of AchE which may result in improvement in the level of acetylcholine in postmenopausal rats. Inhibition of the enzyme AchE also leads to a decrease in $A \beta$ formation and its aggregation, thereby decreasing the progression of memory impairment.

In menopause due to low level of estrogen, the formation of ROS and oxidative stress increases. It may occur due to the interaction between protein and oxygen. Estrogen generally causes a decrease in oxidative stress in the body due to its antioxidant properties. In menopausal women decreased level of estrogen leads to more formation of free radical and oxidative stress. In this study, high level of malondialdehyde, which is a product of lipid peroxidation in estrogen deficient postmenopausal rats indicative oxidative damage of ovaries in postmenopausal rats. Administration of kernels of $J R$ for 45 days significantly decreased the level of malondialdehyde and increased the level of antioxidant enzyme superoxide dismutase and antioxidant reduced glutathione (GSH). Reduced glutathione which itself is a nonenzymatic defense antioxidant acts a substrate for various antioxidant enzymes such as GST and GPx, thereby protecting cellular constituents from peroxides and ROS which are 


\section{www.ijppr.humanjournals.com}

formed during metabolism. Excessive utilization of GSH by glutathione S transferase and GPx in VCD treated rat's leads to depletion of GSH. It may be conclude that the flavonoids, polyphenols and phenolic compounds present in the paste of $J R$ are responsible for decreasing the oxidative stress in postmenopausal female rats.

Histopathological examination of ovaries shows that VCD caused significant inertia and atrophy of ovarian cells and endometrium. The ovaries of rats after treatment of 45 days paste of dried kernel of $J R$ show a mild to moderate decrease in several primordial follicles and increase corpus luteum in minute amount. Whereas the endometrium of rats after 45 days of treatment shows mild simple hyperplasia without structural abnormality. Kernels of $J R$ caused only mild improvement in the cells of ovaries and endometrium without having any effect on ovarian follicles. The phytoestrogens and flavones present in the kernels of $J R$ might contribute to this effect.

\section{CONCLUSION}

Based on results, it can be concluded that intake of the dried kernels of $J R$ for a long period and on regular basis can exert a protective effect in females from menopause induced complications like cognition, metabolic disorders, osteoporosis, and cardiovascular risks. However future studies are required to establish the effect of dried kernels of $J R$ at different stages of menopause in female rats. The kernel of $J R$ decreased the level of oxidative stress and restored the level of antioxidant enzymes due to the presence of phenolic compounds and flavanoids present on it.

\section{REFERENCES}

1. Eaker E. M. Winston. Cardiovascular disease in women Circulation. 1993;88:1999-2009.

2. Milsom I. Menopause-related symptoms and their treatment. The menopause. 2006:9-16.

3. Constitution A. Diagnosing Menopause.

4. Dutton PJ, Rymer JM. Physiology of the menstrual cycle and changes in the perimenopause. Managing the Menopause: 21st Century Solutions. 2015.

5. Fischl F. Definition and Pathophysiology. Menopause Andropause: Hormone replacement therapy through the ages new cognition and therapy concepts Krause \& Pachernegg GmbH. 2000:29-32.

6. Bruce D, Rymer J. Symptoms of the menopause. Best Practice \& Research Clinical Obstetrics \& Gynaecology. 2009;23(1):25-32.

7. Utian WH. Psychosocial and socioeconomic burden of vasomotor symptoms in menopause: a comprehensive review. Health and Quality of Life outcomes. 2005;3(1):47.

8. Lassila H, Johns NP, O’Neil CK, Johns JR, Balk JL, Witt-Enderby PA. Alternative Options to Manage Menopausal Symptoms with a Focus on Melatonin and Osteoporosis. Clin Pharmacol Biopharm. 2014;3(115):2.

9. Fitzpatrick LA. Estrogen therapy for postmenopausal osteoporosis. Arquivos Brasileiros de Endocrinologia \& Metabologia. 2006;50(4):705-19. 
10. Abraham A, Pullishery F. The effect of menopause on the periodontium-A review. J Interdiscipl Mes Dent Sci. $2015 ; 14: 79-82$.

11. Qureshi HJ, Hussain G, Jafary ZA, Bashir MU, Latif N, Riaz Z. Calcium status in premenopausal and postmenopausal women. Journal of Ayub Medical College Abbottabad. 2010;22(2):143-5.

12. Sharma R, Sharma P, Kumar P, Gupta G. Role of magnesium in post-menopausal women with osteoporosis and osteopenia. Asian J Pharm Clin Res. 2016;9(1):198-9.

13. Doshi SB, Agarwal A. The role of oxidative stress in menopause. Journal of mid-life health. 2013;4(3):140.

14. Chandrasekhar V. Diabetes and Menopause. J Anesth Crit Care Open Access. 2016;6(4):00233.

15. Mendelsohn ME, Karas RH. The protective effects of estrogen on the cardiovascular system. New England journal of medicine. 1999;340(23):1801-11.

16. Luine VN. Estradiol and cognitive function: past, present and future. Hormones and behavior. 2014;66(4):602-18.

17. WOMEN IP. NEUROENDOCRINE CHANGES AND ALZHEIMER DISEASE.

18. Eichling PS, Sahni J. Menopause related sleep disorders. Journal of Clinical Sleep Medicine. 2005;1(03):291-300.

19. Mamatha M. An overview of Menopausal Hormone Replacement Therapy (MHRT). 2016.

20. Manson JE, Chlebowski RT, Stefanick ML, Aragaki AK, Rossouw JE, Prentice RL, et al. Menopausal hormone therapy and health outcomes during the intervention and extended poststopping phases of the Women's Health Initiative randomized trials. Jama. 2013;310(13):1353-68.

21. Lobo RA. Hormone-replacement therapy: current thinking. Nature Reviews Endocrinology. 2017;13(4):220.

22. Ososki AL, Kennelly EJ. Phytoestrogens: a review of the present state of research. Phytotherapy Research: An International Journal Devoted to Pharmacological and Toxicological Evaluation of Natural Product Derivatives. 2003;17(8):845-69.

23. Sunita P, Pattanayak S. Phytoestrogens in postmenopausal indications: A theoretical perspective. Pharmacognosy reviews. 2011;5(9):41.

24. Shah TI, Sharma E, Ahmad G. Juglans regia Linn: A phytopharmacological review. World J Pharm Sci. 2014;2(4):363-73.

25. Jaiswal BS, Tailang M. Juglans regia: A review of its traditional uses phytochemistry and pharmacology. Indo Am J Pharm Res. 2017;7:390-8.

26. Mao X, Hua Y, Chen G. Amino acid composition, molecular weight distribution and gel electrophoresis of walnut (Juglans regia L.) proteins and protein fractionations. International journal of molecular sciences. 2014;15(2):2003-14.

27. Poulose SM, Bielinski DF, Shukitt-Hale B. Walnut diet reduces accumulation of polyubiquitinated proteins and inflammation in the brain of aged rats. The Journal of nutritional biochemistry. 2013;24(5):912-9.

28. Hoyer PB, Sipes IG. Assessment of follicle destruction in chemical-induced ovarian toxicity. Annual review of pharmacology and toxicology. 1996;36(1):307-31.

29. Pellow S, Chopin P, File SE, Briley M. Validation of open: closed arm entries in an elevated plus-maze as a measure of anxiety in the rat. Journal of neuroscience methods. 1985;14(3):149-67.

30. Morris R. Developments of a water-maze procedure for studying spatial learning in the rat. Journal of neuroscience methods. 1984;11(1):47-60.

31.Long JA, Evans HM. The oestrous cycle in the rat and its associated phenomena: University of California Press; 1922.

32. MACDONALD PC, MADDEN JD, BRENNER PF, WILSON JD, SIITERI PK. Origin of estrogen in normal men and in women with testicular feminization. The Journal of Clinical Endocrinology \& Metabolism. 1979;49(6):905-16.

33. Castelli WP, Doyle JT, Gordon T, Hames CG, Hjortland MC, Hulley SB, et al. HDL cholesterol and other lipids in coronary heart disease. The cooperative lipoprotein phenotyping study. Circulation. 1977;55(5):767-72. 34. Rust MB, Faulhaber Jr, Budack MK, Pfeffer C, Maritzen T, Didié M, et al. Neurogenic mechanisms contribute to hypertension in mice with disruption of the $\mathrm{K}-\mathrm{Cl}$ cotransporter $\mathrm{KCC} 3$. Circulation research. 2006;98(4):549-56. 


\section{www.ijppr.humanjournals.com}

35. Miller NE, Thelle D, Forde O, Mjos O. THE TROMSOHEART-STUDY: HIGH-DENSITY LIPOPROTEIN AND CORONARY HEART-DISEASE: A PROSPECTIVE CASE-CONTROL STUDY. The Lancet. 1977;309(8019):965-8.

36. Stevens J, Tsang W, Newall R. Measurement of the enzymes lactate dehydrogenase and creatine kinase using reflectance spectroscopy and reagent strips. Journal of clinical pathology. 1983;36(12):1371-6.

37. Robinson HW, Hogden CG. The biuret reaction in the determination of serum proteins. 2. Measurements made by a Duboscq colorimeter compared with values obtained by the Kjeldahl procedure. Journal of Biological Chemistry. 1940;135:727-31.

38. Mann CK, Yoe JH. Spectrophotometric determination of magnesium with 1-azo-2-hydroxy-3-(2.4dimethylcarboxanilido)-naphtha-lene-1-(2-hydroxybenzene). Analytica chimica acta. 1957;16:155-60.

39. Fiske CH, Subbarow Y. The colorimetric determination of phosphorus. J biol Chem. 1925;66(2):375-400.

40. Nguyen A, Aerts T, Van Dam D, De Deyn P. Biogenic amines and their metabolites in mouse brain tissue: Development, optimization and validation of an analytical HPLC method. Journal of Chromatography B. 2010;878(29):3003-14.

41.Ellman GL, Courtney KD, Andres Jr V, Featherstone RM. A new and rapid colorimetric determination of acetylcholinesterase activity. Biochemical pharmacology. 1961;7(2):88-95.

42. Slater T, Sawyer B. The stimulatory effects of carbon tetrachloride and other halogenoalkanes on peroxidative reactions in rat liver fractions in vitro. General features of the systems used. Biochemical Journal. 1971;123(5):805-14.

43. Misra HP, Fridovich I. The role of superoxide anion in the autoxidation of epinephrine and a simple assay for superoxide dismutase. Journal of Biological chemistry. 1972;247(10):3170-5.

44. Moron MS, Depierre JW, Mannervik B. Levels of glutathione, glutathione reductase and glutathione Stransferase activities in rat lung and liver. Biochimica et Biophysica Acta (BBA)-General Subjects. 1979;582(1):67-78.

45. Oral A, Odabasoglu F, Halici Z, Keles ON, Unal B, Coskun AK, et al. Protective effects of montelukast on ischemia-reperfusion injury in rat ovaries subjected to torsion and detorsion: biochemical and histopathologic evaluation. Fertility and sterility. 2011;95(4):1360-6.

46. Rao Y-Q, Li J, Wang W-J. Effects of Gengnianchun on learning and memory ability, neurotransmitter, cytokines, and leptin in ovariectomized rats. International journal of clinical and experimental medicine. 2015;8(6):8648.

47. Hoyer PB, Devine PJ, Hu X, Thompson KE, Sipes IG. Ovarian toxicity of 4-vinylcyclohexene diepoxide: a mechanistic model. Toxicologic Pathology. 2001;29(1):91-9.

48. Sarrafzadegan N, Khosravi-Boroujeni H, Esmaillzadeh A, Sadeghi M, Rafieian-Kopaei M, Asgary S. The association between hypertriglyceridemic waist phenotype, menopause, and cardiovascular risk factors. Archives of Iranian medicine. 2013;16(3):161-6.

49. Gotto AM, Brinton EA. Assessing low levels of high-density lipoprotein cholesterol as a risk factor in coronary heart disease: a working group report and update. Journal of the American College of Cardiology. 2004;43(5):717-24.

50.Jungbauer A, Medjakovic S. Phytoestrogens and the metabolic syndrome. The Journal of steroid biochemistry and molecular biology. 2014;139:277-89.

51. Rishi R. Phytoestrogens in health and illness. Indian journal of pharmacology. 2002;34(5):311-20.

52. Wilmink HW, de Kleijn MJ, Bots ML, Bak AA, van der Schouw YT, Engelen S, et al. Lipoprotein (a) is associated with endothelial function in healthy postmenopausal women. Atherosclerosis. 2000;153(1):249-54.

53. Nikander E, Metsä-Heikkilä M, Ylikorkala O, Tiitinen A. Effects of phytoestrogens on bone turnover in postmenopausal women with a history of breast cancer. The Journal of Clinical Endocrinology \& Metabolism. 2004;89(3):1207-12.

54. Xu X, Duncan AM, Wangen KE, Kurzer MS. Soy consumption alters endogenous estrogen metabolism in postmenopausal women. Cancer Epidemiology and Prevention Biomarkers. 2000;9(8):781-6. 
Table No. 1: Effect of paste of dried kernel of Juglans regia on serum Cholesterol, TG, HDL, VLDL LDL and AI level in ovotoxicity induced postmenopausal complications in female rats.

\begin{tabular}{|c|c|c|c|c|c|c|c|c|c|}
\hline \multirow{2}{*}{$\begin{array}{l}\text { Treatmen } \\
\mathbf{t} \\
\text { (i.p.p.o.) }\end{array}$} & \multicolumn{3}{|c|}{ Cholesterol (mg/dI) } & \multicolumn{3}{|c|}{ Triglyceride (mg/dl) } & \multicolumn{3}{|c|}{ High Density Lipoprotein (mg/dl) } \\
\hline & 0 Day & 15 Day & 60 Day & 0 Day & 15 Day & $60 \mathrm{Day}$ & 0 Day & 15 Day & 60 Day \\
\hline Normal & $78.1 \pm 3.57$ & $\begin{array}{l}83.19 \pm 1.3 \\
8\end{array}$ & \begin{tabular}{|l}
$77.63 \pm 3.3$ \\
2
\end{tabular} & $\begin{array}{l}52.09 \pm 0.6 \\
6\end{array}$ & $52.85 \pm 0.57$ & $\begin{array}{l}54.69 \pm 1.8 \\
1\end{array}$ & $\begin{array}{l}31.58 \pm 0.4 \\
5\end{array}$ & $\begin{array}{l}30.63 \pm 0.4 \\
8\end{array}$ & $\begin{array}{l}32.42 \pm 0.7 \\
1\end{array}$ \\
\hline VCD & $\begin{array}{l}77.34 \pm 3.7 \\
3\end{array}$ & $\begin{array}{l}125.7 \pm 2.9 \\
0=\end{array}$ & $\begin{array}{l}133.3 \pm 3.5 \\
5\end{array}$ & $\begin{array}{l}52.36 \pm 1.7 \\
9\end{array}$ & $\begin{array}{l}92.49=0.86 \\
=\end{array}$ & $\begin{array}{l}89.92 \pm 0.5 \\
7\end{array}$ & $\begin{array}{l}32.35=0.9 \\
2\end{array}$ & $\begin{array}{l}18.23 \pm 0.8 \\
1^{b}\end{array}$ & $\begin{array}{l}12.33 \pm 0.4 \\
3\end{array}$ \\
\hline $\begin{array}{l}\text { Paste } 100 \\
\mathrm{mg} / \mathrm{kg}\end{array}$ & $\begin{array}{l}87.07 \pm 3.2 \\
6\end{array}$ & $\begin{array}{l}98.96 \pm 1.9 \\
2^{b}\end{array}$ & $\begin{array}{l}90.05 \pm 2.4 \\
5\end{array}$ & $58.5 \pm 2.21$ & $74.95 \pm 3.17$ & $\begin{array}{l}65.73 \pm 2.0 \\
7\end{array}$ & \begin{tabular}{|l}
$29.43 \pm 2.1$ \\
0
\end{tabular} & $\begin{array}{l}15.75=0.5 \\
8^{\circ}\end{array}$ & $\begin{array}{l}21.95 \pm 1.4 \\
0\end{array}$ \\
\hline $\begin{array}{l}\text { Paste } 200 \\
\mathrm{mg} / \mathrm{kg}\end{array}$ & $\begin{array}{l}83.18 \pm 4.5 \\
0\end{array}$ & $\begin{array}{l}101.2 \pm 2.2 \\
2^{b}\end{array}$ & ${ }_{1}^{77.66 \pm 3.6}$ & $\begin{array}{l}59.11=1.3 \\
9\end{array}$ & $76.72 \pm 1.54$ & $\begin{array}{l}57.58 \pm 0.5 \\
0\end{array}$ & $\begin{array}{l}30.86 \pm 1.7 \\
8\end{array}$ & $\begin{array}{l}15.88 \pm 0.6 \\
8=\end{array}$ & $\begin{array}{l}26.63=0.7 \\
8\end{array}$ \\
\hline $\begin{array}{l}\text { Paste } 400 \\
\mathrm{mg} / \mathrm{kg}\end{array}$ & $\begin{array}{l}82.16 \pm 5.1 \\
1\end{array}$ & $\begin{array}{l}109.2 \pm 2.5 \\
7=\end{array}$ & $\begin{array}{l}67.34 \pm 1.7 \\
0 \cdots\end{array}$ & $\begin{array}{l}57.38 \pm 2.3 \\
0\end{array}$ & $78.57 \pm 1.69$ & $\begin{array}{l}52.07 \pm 0.8 \\
6 * 8 *\end{array}$ & \begin{tabular}{|l}
$29.83 \pm 1.5$ \\
9
\end{tabular} & $\begin{array}{l}15.94=0.6 \\
3^{\circ}\end{array}$ & $\begin{array}{l}32.13=1.2 \\
2 \cdots\end{array}$ \\
\hline Estrogen & $\begin{array}{l}77.37 \pm 1.1 \\
1\end{array}$ & $\begin{array}{l}95.83 \pm 3.9 \\
4^{b}\end{array}$ & $\begin{array}{l}63.96 \pm 0.2 \\
6 \cdots\end{array}$ & $\begin{array}{l}54.93 \pm 0.5 \\
6\end{array}$ & $\begin{array}{l}94.71=0.28 \\
=\end{array}$ & $\begin{array}{l}47.22 \pm 0.5 \\
7 * 8 *\end{array}$ & $\begin{array}{l}32.59=0.8 \\
5\end{array}$ & $\begin{array}{l}18.51=0.3 \\
3^{\circ}\end{array}$ & $\begin{array}{l}48.47 \pm 0.4 \\
7 \cdots\end{array}$ \\
\hline \multirow{2}{*}{$\begin{array}{l}\text { Treatmen } \\
\mathbf{t} \\
\text { (i.p.p.o.) }\end{array}$} & \multicolumn{3}{|c|}{\begin{tabular}{|l}
$\begin{array}{l}\text { Very Low } \\
(\mathbf{m g} / \mathrm{dl})\end{array}$ \\
\end{tabular}} & \multicolumn{3}{|c|}{ Low Density Lipoprotein (mg/dl) } & \multicolumn{3}{|c|}{ Atherogenic Index } \\
\hline & 0 Day & 15 Day & 60 Day & 0 Day & 15 Day & 60 Day & 0 Day & 15 Day & $60 \mathrm{Day}$ \\
\hline Normal & $\begin{array}{l}10.42 \pm 0.1 \\
3\end{array}$ & $\begin{array}{l}10.56 \pm 0.1 \\
1\end{array}$ & $\begin{array}{l}10.93 \pm 0.3 \\
6\end{array}$ & $\begin{array}{l}36.11 \pm 3.7 \\
0\end{array}$ & $41.37 \pm 1.39$ & $\begin{array}{l}34.28 \pm 3.6 \\
9\end{array}$ & $1.47 \pm 0.12$ & $1.71 \pm 0.05$ & $1.39 \pm 0.13$ \\
\hline VCD & $\begin{array}{l}10.47 \pm 0.3 \\
6\end{array}$ & $\begin{array}{l}18.49=0.1 \\
7^{5}\end{array}$ & $\begin{array}{l}17.98 \pm 0.1 \\
1\end{array}$ & $\begin{array}{l}34.5 l=4.6 \\
7\end{array}$ & $\begin{array}{l}106.4 \pm 19.9 \\
4=\end{array}$ & $103 \pm 3.53$ & $1.39 \pm 0.18$ & $\begin{array}{l}5.94 \pm 0.37 \\
=\end{array}$ & $9.85 \pm 0.49$ \\
\hline $\begin{array}{l}\text { Paste } 100 \\
\mathrm{mg} / \mathrm{kg}\end{array}$ & $11.7 \pm 0.44$ & $\begin{array}{l}14.99=0.6 \\
3=\end{array}$ & $\begin{array}{l}13.15=0.4 \\
1\end{array}$ & $\begin{array}{l}45.93 \pm 3.6 \\
7\end{array}$ & $68.22 \pm 2.12$ & $\begin{array}{l}54.88 \pm 3.7 \\
7^{+}\end{array}$ & $1.99 \pm 0.22$ & $5.30 \pm 0.23$ & $3.17 \pm 0.35$ \\
\hline $\begin{array}{l}\text { Paste } 200 \\
\mathrm{mg} / \mathrm{kg}\end{array}$ & $\begin{array}{l}11.82 \pm 0.2 \\
8\end{array}$ & $\begin{array}{l}15.34=0.3 \\
1:\end{array}$ & $11.52 \pm 0.1$ & $40.5 \pm 5.26$ & $69.94 \pm 2.49$ & $39.52 \pm 3.3$ & $1.73 \pm 0.24$ & $5.42 \pm 0.40$ & $1.92 \pm 0.12$ \\
\hline $\begin{array}{l}\text { Paste } 400 \\
\mathrm{mg} / \mathrm{kg}\end{array}$ & $\begin{array}{l}11.48 \pm 0.4 \\
6\end{array}$ & $\begin{array}{l}15.71=0.3 \\
4\end{array}$ & $10.41=0.1$ & $\begin{array}{l}40.85 \pm 3.3 \\
0\end{array}$ & $\begin{array}{l}77.51 \pm 2.52 \\
=\end{array}$ & $24.8 \pm 1.53$ & $1.75 \pm 0.05$ & $5.88 \pm 0.31$ & $1.10 \pm 0.07$ \\
\hline Estrogen & $\begin{array}{l}10.99=0.1 \\
1\end{array}$ & $\begin{array}{l}18.94=0.0 \\
6^{b}\end{array}$ & $\begin{array}{l}9.441=0.1 \\
1 \cdots\end{array}$ & $\begin{array}{l}34.29 \pm 1.5 \\
1\end{array}$ & $58.38 \pm 4.10$ & $6.05 \pm 0.56$ & $1.38 \pm 0.09$ & $4.18 \pm 0.27$ & $0.32 \pm 0.01$ \\
\hline
\end{tabular}

All values are mean \pm SEM; $N=6$ in group, one way ANOVA followed by Donetts multiple comparison test is applied for statistical analysis. $\mathrm{P}$ values: $* \mathrm{P}<0.05, * * \mathrm{P}<0.01, * * * \mathrm{P}<0.001$ when the results of day 60 were compared with the result of day 15 for each group. ${ }^{c} \mathrm{P}<0.05$, ${ }^{b} \mathrm{P}<0.01,{ }^{\mathrm{a}} \mathrm{P}<0.001$ when results of day 15 were compared with day one of the study. 
www.ijppr.humanjournals.com

Table No. 2: Effect of paste of dried kernel of Juglans regia on serum Calcium, Magnesium and Phosphorus level in ovotoxicity induced postmenopausal complications in female rats.

\begin{tabular}{|c|c|c|c|c|c|c|c|c|c|}
\hline \multirow{2}{*}{$\begin{array}{l}\text { Treatment } \\
\text { (i.p } / \text { p.o.) }\end{array}$} & \multicolumn{3}{|c|}{ Calcium (mg/dl) } & \multicolumn{3}{|c|}{ Magnesium (mg/dl) } & \multicolumn{3}{|c|}{ Phosphorus (mg/dl) } \\
\hline & 0 Day & 15 Day & 60 Day & 0 Day & 15 Day & 60 Day & 0 Day & 15 Day & 60 Day \\
\hline Normal & $6.46 \pm 0.45$ & $6.75 \pm 0.30$ & $6.59 \pm 0.44$ & $2.13 \pm 0.04$ & $1.97 \pm 0.19$ & $2.14 \pm 0.03$ & $6.51 \pm 0.28$ & $6.94 \pm 0.41$ & $6.95 \pm 0.22$ \\
\hline $\mathrm{VCD}$ & $7.2 \pm 0.63$ & $\begin{array}{l}15.15 \pm 0.69 \\
\text { a }\end{array}$ & $13.91 \pm 0.89$ & $2.03 \pm 0.06$ & $\begin{array}{l}5.22 \pm 0.21 \\
\mathrm{a}\end{array}$ & $5.99 \pm 0.05$ & $5.79 \pm 0.17$ & $\begin{array}{l}13.77 \pm 0.85 \\
b\end{array}$ & $13.1 \pm 0.52$ \\
\hline $\begin{array}{l}\text { Paste } 100 \\
\mathrm{mg} / \mathrm{kg}\end{array}$ & $7.98 \pm 1.23$ & $\begin{array}{l}15.08 \pm 1.36 \\
\mathrm{a}\end{array}$ & $11.62 \pm 0.73$ & $2.05 \pm 0.94$ & $\begin{array}{l}4.40 \pm 0.32 \\
b\end{array}$ & $3.01 \pm 0.13$ & $5.95 \pm 0.36$ & $\begin{array}{l}14.5 \pm 0.44 \\
b\end{array}$ & $10.4 \pm 0.21$ \\
\hline $\begin{array}{l}\text { Paste } 200 \\
\mathrm{mg} / \mathrm{kg}\end{array}$ & $8.3 \pm 0.93$ & $\begin{array}{l}15.63 \pm 1.12 \\
\mathrm{a}\end{array}$ & $9.1 \pm 0.34$ & $1.98 \pm 0.10$ & $\begin{array}{l}4.63 \pm 0.45 \\
\mathrm{a}\end{array}$ & $2.97 \pm 0.12$ & $6.52 \pm 0.46$ & $\begin{array}{l}13.47 \pm 0.63 \\
b\end{array}$ & $9.49 \pm 0.18$ \\
\hline $\begin{array}{l}\text { Paste } 400 \\
\mathrm{mg} / \mathrm{kg}\end{array}$ & $8.46 \pm 0.86$ & $\begin{array}{l}16.38 \pm 0.80 \\
\text { a }\end{array}$ & $7.13 \pm 0.64$ & $1.99 \pm 0.09$ & $\begin{array}{l}4.51 \pm 0.33 \\
\text { a }\end{array}$ & $1.89 \pm 0.03$ & $6.85 \pm 0.43$ & $\begin{array}{l}15.26 \pm 0.63 \\
\text { a }\end{array}$ & $6.37 \pm 0.47$ \\
\hline
\end{tabular}

All values are mean $\pm \mathrm{SEM} ; \mathrm{N}=6$ in group, one way ANOVA followed by Donetts multiple comparison test is applied for statistical analysis. $\mathrm{P}$ values: $* \mathrm{P}<0.05, * * \mathrm{P}<0.01, * * * \mathrm{P}<0.001$ when the results of day 60 were compared with the result of day 15 for each group. ${ }^{c} \mathrm{P}<0.05$, ${ }^{b} \mathrm{P}<0.01,{ }^{a} \mathrm{P}<0.001$ when results of day 15 were compared with day one of the study.

Table No. 3: Effect of paste of dried kernel of Juglans regia on tissues LPO, SOD and GSH level in ovotoxicity induced postmenopausal complications in female rats.

\begin{tabular}{|l|c|c|c|}
\hline \multicolumn{1}{|c|}{$\begin{array}{c}\text { Treatment } \\
\text { (i.p./p.o.) }\end{array}$} & LPO (mol/l) on 60 Day & SOD (EU/dl) on 60 Day & GSH $(\boldsymbol{\mu g} / \mathbf{m g})$ on 60 Day \\
\hline Normal & $46.02 \pm 2.08$ & $102.4 \pm 1.78$ & $120.8 \pm 3.53$ \\
\hline VCD & $138 \pm 11.45^{\text {a }}$ & $53.68 \pm 1.79^{\text {a }}$ & $54.12 \pm 1.73^{\text {a }}$ \\
\hline Paste $100 \mathrm{mg} / \mathrm{kg}$ & $93.99 \pm 1.98$ & $58.84 \pm 0.67$ & $66.6 \pm 1.92$ \\
\hline Paste $200 \mathrm{mg} / \mathrm{kg}$ & $83.78 \pm 1.42^{*}$ & $67.73 \pm 2.32^{*}$ & $73.59 \pm 1.98^{*}$ \\
\hline Paste $400 \mathrm{mg} / \mathrm{kg}$ & $59.07 \pm 1.70^{* *}$ & $90.88 \pm 1.88^{* *}$ & $91.91 \pm 2.99^{* *}$ \\
\hline Estrogen & $46.11 \pm 1.68^{* * *}$ & $100.6 \pm 1.33^{* *}$ & $106.4 \pm 3.95^{* *}$ \\
\hline
\end{tabular}


All values are mean $\pm \mathrm{SEM} ; \mathrm{N}=6$ in group, one way ANOVA followed by Donetts multiple comparison test is applied for statistical analysis. $\mathrm{P}$ values: $* \mathrm{P}<0.05, * * \mathrm{P}<0.01, * * * \mathrm{P}<0.001$ when the results of the treated groups were compared with the control group. When the results of the control group was compared with the normal group.

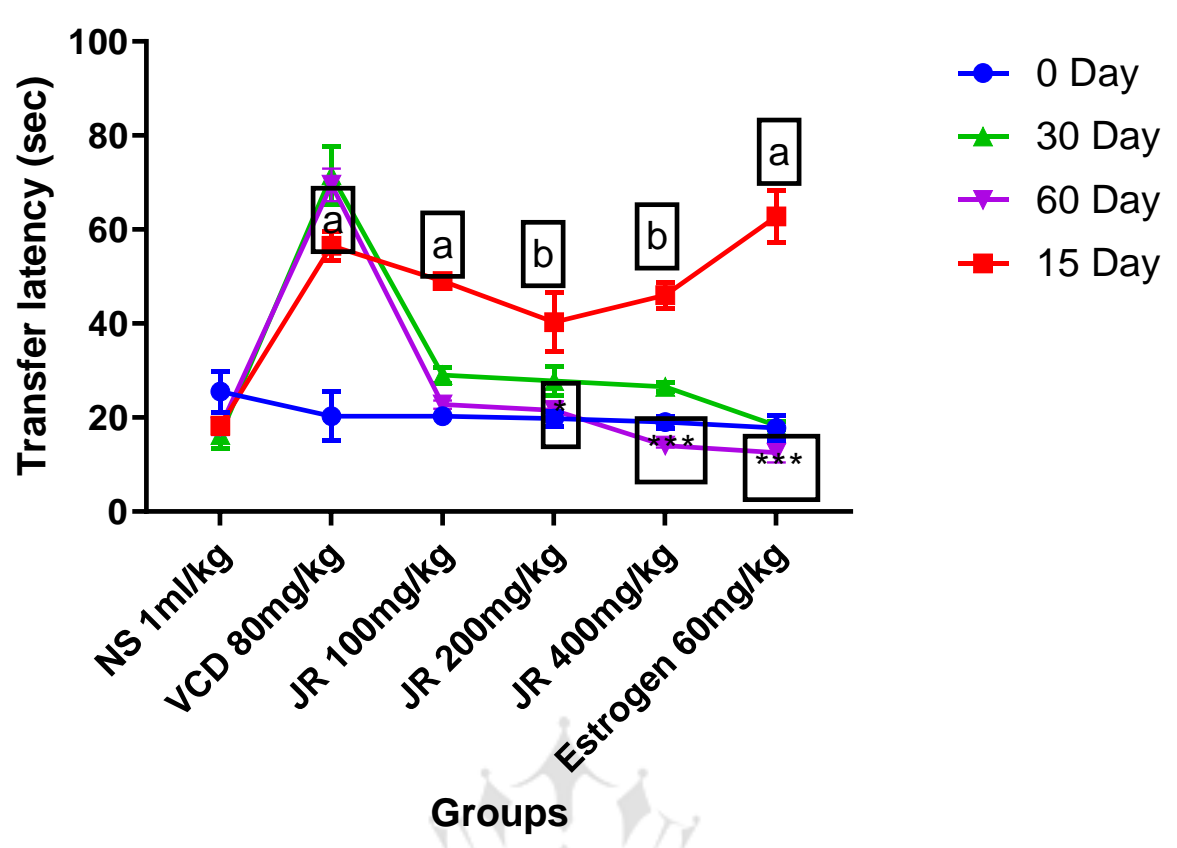

Figure No. 1: Effect of paste of dried kernel of Juglans regia on Transfer latency in ovotoxicity induced cognitive impairment in female rats using the Elevated Plus Maze apparatus.

All values are mean $\pm \mathrm{SEM} ; \mathrm{N}=6$ in group, one way ANOVA followed by Donetts multiple comparison test is applied for statistical analysis. $\mathrm{P}$ values: $* \mathrm{P}<0.05, * * \mathrm{P}<0.01, * * * \mathrm{P}<0.001$ when the results of day 60 were compared with the result of day 15 for each group. ${ }^{c} \mathrm{P}<0.05$, ${ }^{b} \mathrm{P}<0.01,{ }^{\mathrm{a}} \mathrm{P}<0.001$ when results of day 15 were compared with day one of the study.

Index: NS= Normal Saline, $\mathrm{VCD}=4$ - vinyl cyclohexene diepoxide, $J R=j u g l a n s r e g i a$ 


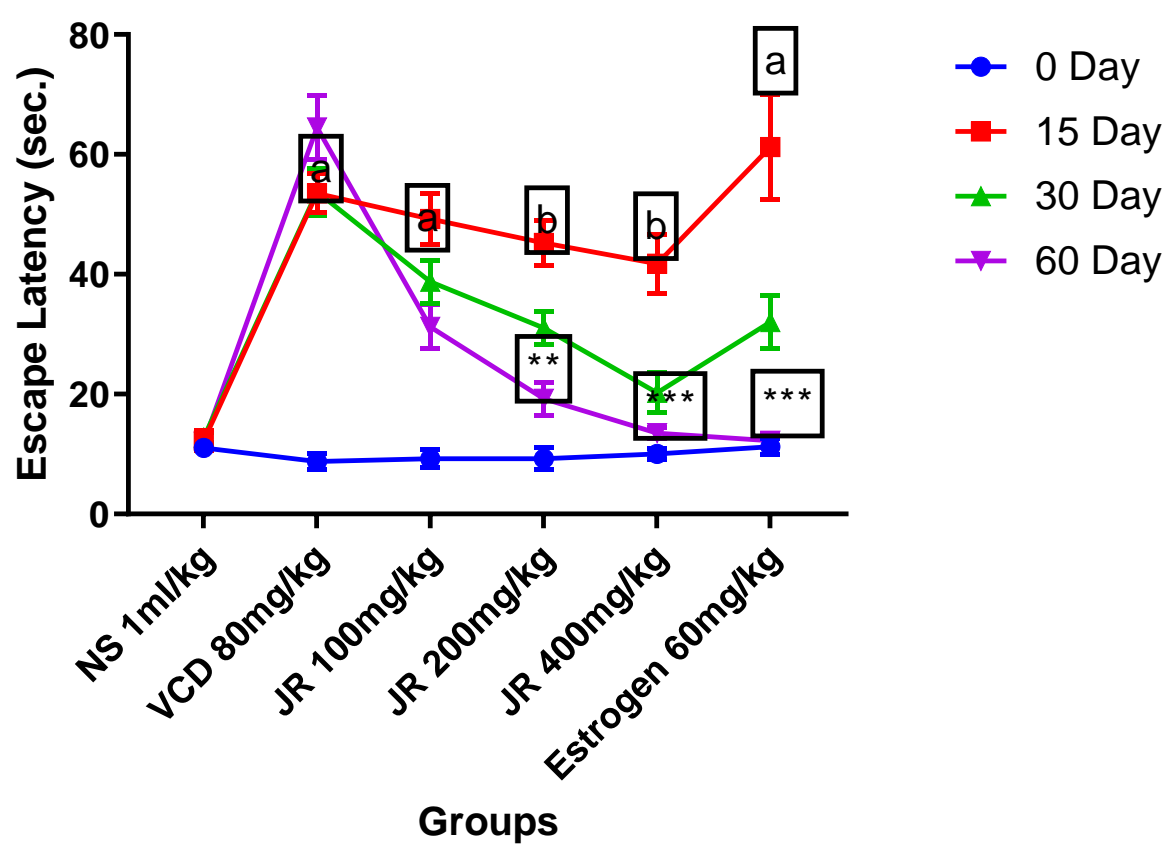

Figure No. 2: Effect of paste of dried kernel of Juglans regia on Escape Latency in ovotoxicity induced cognitive impairment in female rats using Morris Water Maze apparatus.

All values are mean $\pm \mathrm{SEM} ; \mathrm{N}=6$ in group, one way ANOVA followed by Donetts multiple comparison test is applied for statistical analysis. $\mathrm{P}$ values: $* \mathrm{P}<0.05, * * \mathrm{P}<0.01, * * * \mathrm{P}<0.001$ when the results of day 60 were compared with the result of day 15 for each group. ${ }^{c} \mathrm{P}<0.05$, ${ }^{b} \mathrm{P}<0.01,{ }^{\mathrm{a}} \mathrm{P}<0.001$ when results of day 15 were compared with day one of the study.

Index: NS= Normal Saline, VCD= 4-vinyl cyclohaxenediepoxide, $J R=j u g l a n s r e g i a$ 


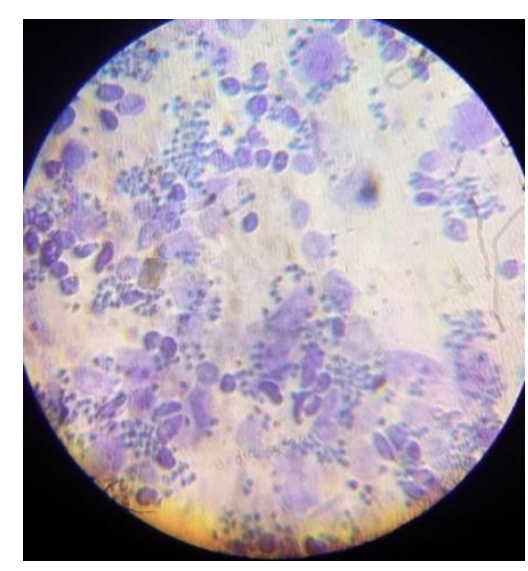

(a)

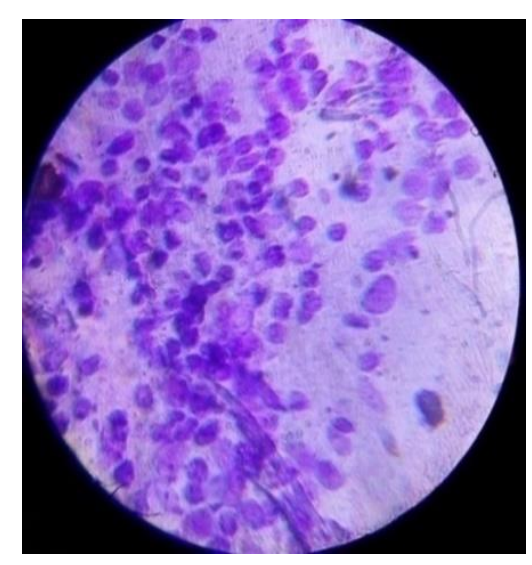

(d)

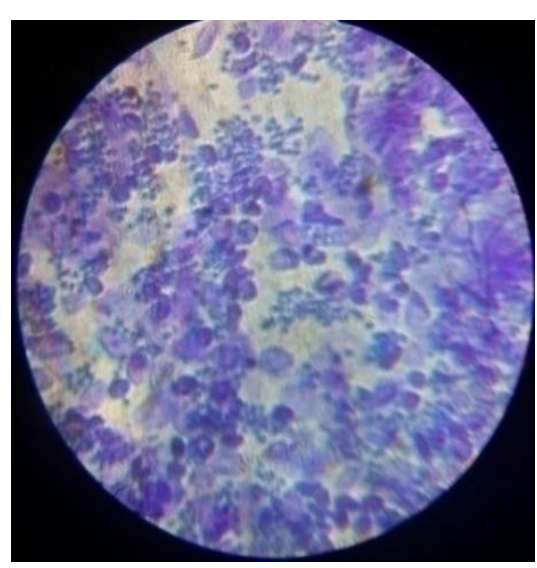

(b)

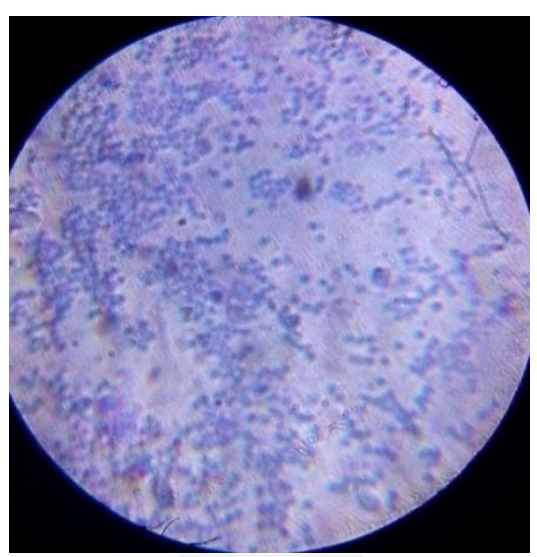

(e)

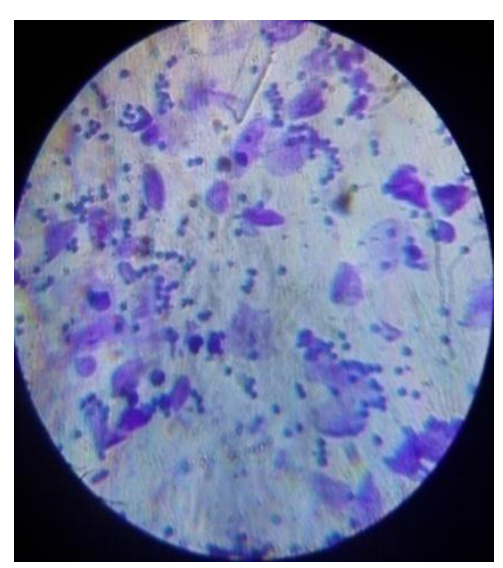

(c)

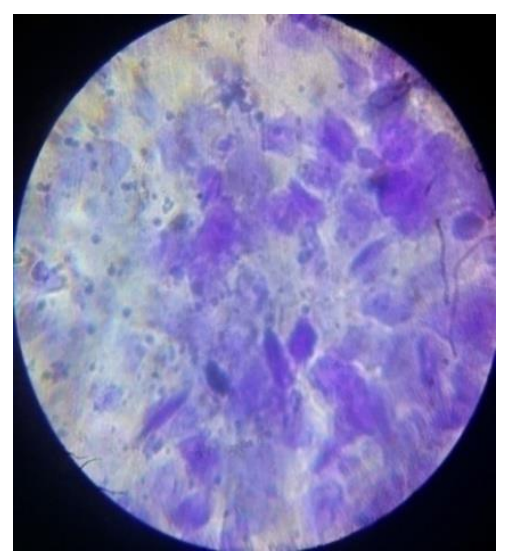

(f)

Figure No. 3: Morphological examination of vaginal smear of all groups of animals in crystal violet dye for evaluating the phase of the menstrual cycle under $\times 10$ magnification. Figure (a) normal group, (b) VCD induced group, (c) paste of $J R$ at 100 $\mathrm{mg} / \mathrm{kg}$ administered group, (d) paste of $J R$ at $200 \mathrm{mg} / \mathrm{kg}$ administered group, (e) paste of $J R$ at $400 \mathrm{mg} / \mathrm{kg}$ administered group, (f) estrogen at $60 \mathrm{mg} / \mathrm{kg}$ administered group.

Index: VCD= 4-vinyl cyclohaxenediepoxide, $J R=j u g l a n s r e g i a$ 


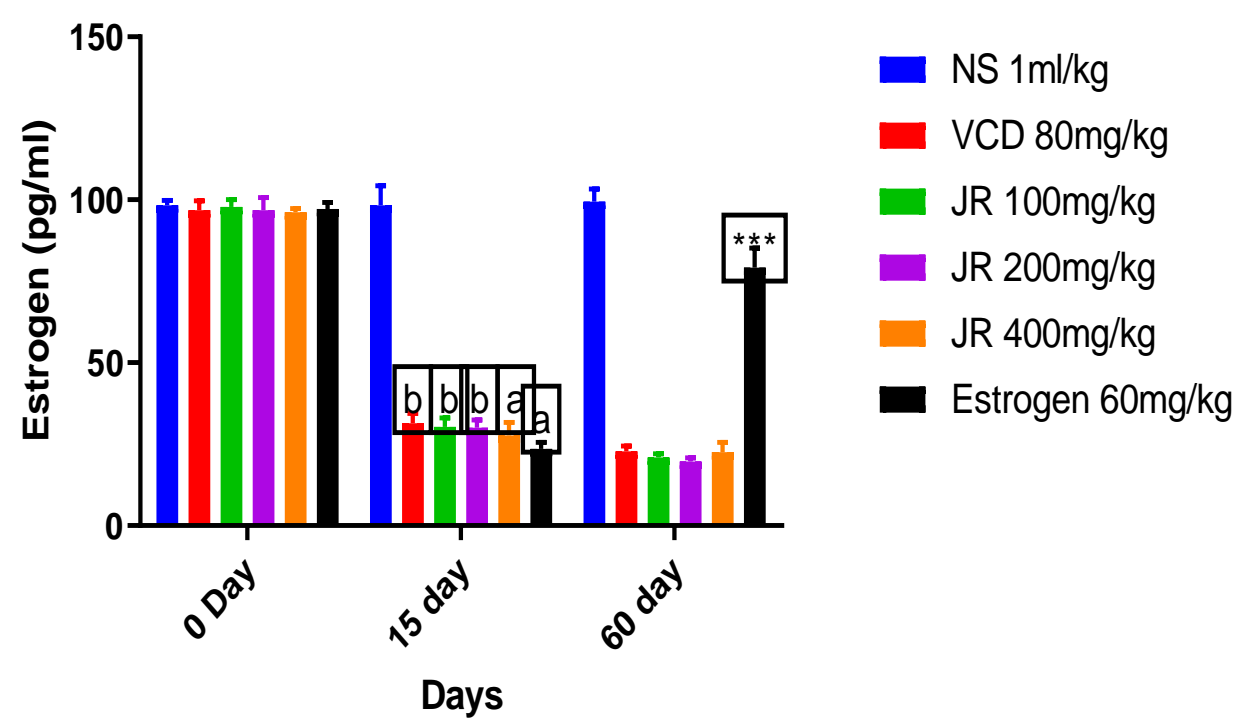

Figure No. 4: Effect of paste of dried kernel of Juglans regia on serum Estrogen level in ovotoxicity induced postmenopausal complications in female rats. All values are mean \pm SEM; $N=6$ in group, one way ANOVA followed by Donetts multiple comparison test is applied for statistical analysis. $\mathbf{P}$ values: $* \mathbf{P}<0.05, * * \mathbf{P}<0.01, * * * \mathbf{P}<0.001$ when the results of day 60 were compared with the result of day 15 for each group. ${ }^{c} P<0.05$, ${ }^{b} \mathbf{P}<0.01$, ${ }^{a} P<0.001$ when results of day 15 were compared with day one of the study.

Index: NS= Normal Saline, $\mathrm{VCD}=4$-vinyl cyclohaxenediepoxide, $J R=j u g l a n s$ regia

(a)

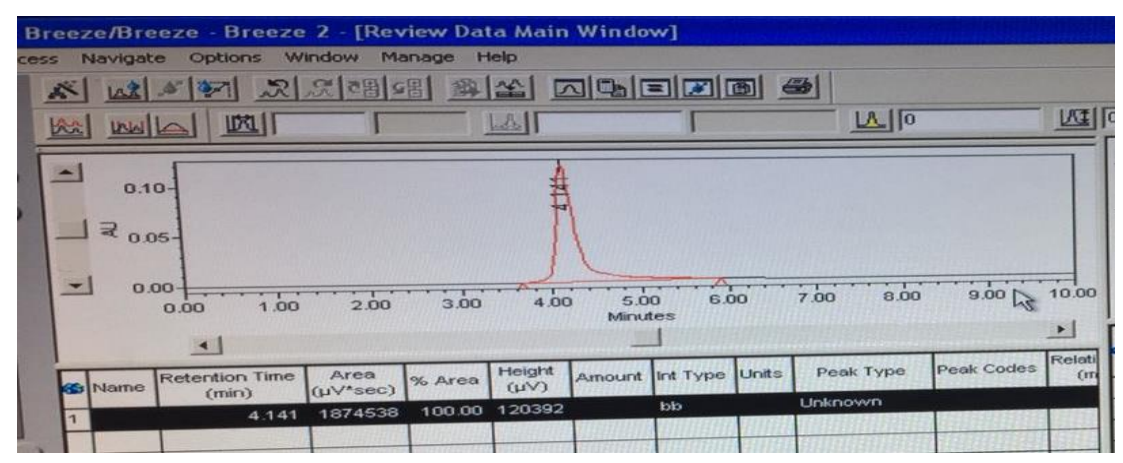


(b)

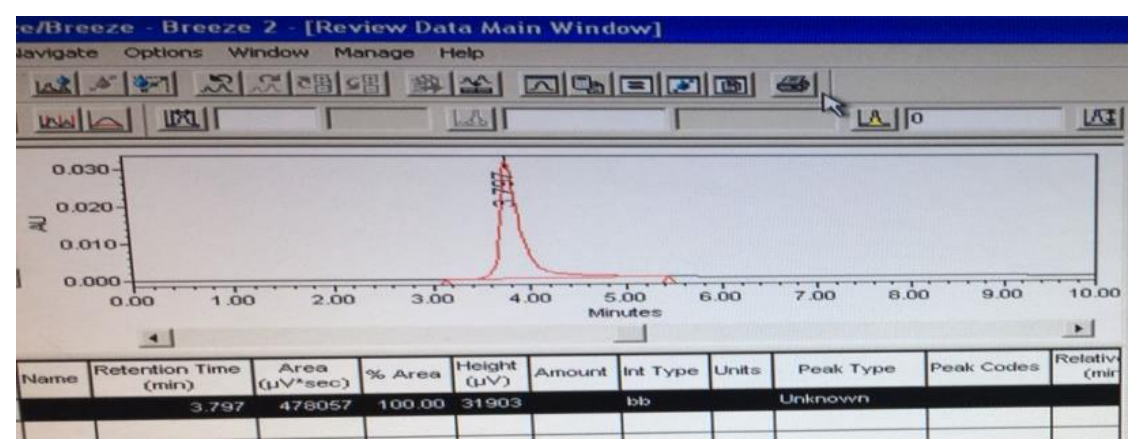

(c)

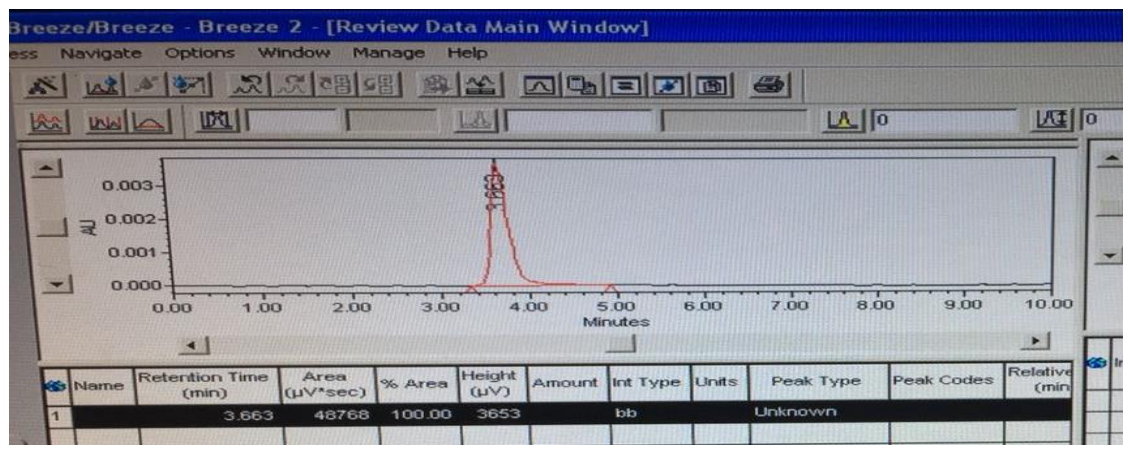

(d)

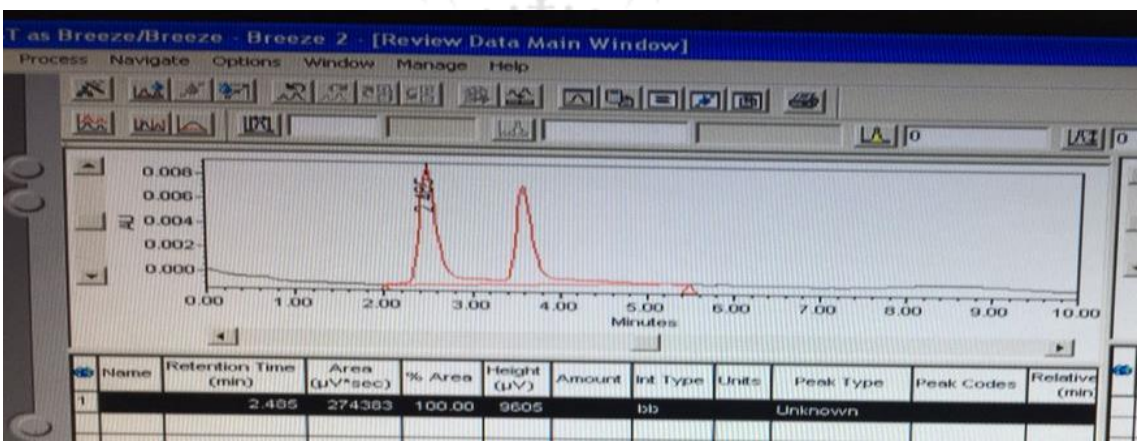

Figure No. 5: Effect of paste of dried kernels of Juglans regia on brain homogenate level of excitatory neurotransmitters in ovotoxicity induced postmenopausal complications in female rats on $60^{\text {th }}$ day. In which graph (a) represent the standard solution of concentration 10ng/ml containing a mixture of NA, A, DA, and 5-HT. The graph (b), (c) and (d) represents brain homogenate levels of excitatory neurotransmitters, for normal female rats, rats of positive control group, rats of group treated with $\mathrm{VCD}+J R(400$ $\mathrm{mg} / \mathrm{kg}$ ) respectively. Index: $\mathrm{NA}=$ Noradrenaline, $\mathrm{A}=$ Adrenaline, $\mathrm{DA}=$ Dopamine, 5HT= Serotonin, VCD= 4-Vinyl cyclohaxenediepoxide, $J R=$ Juglansregia . 


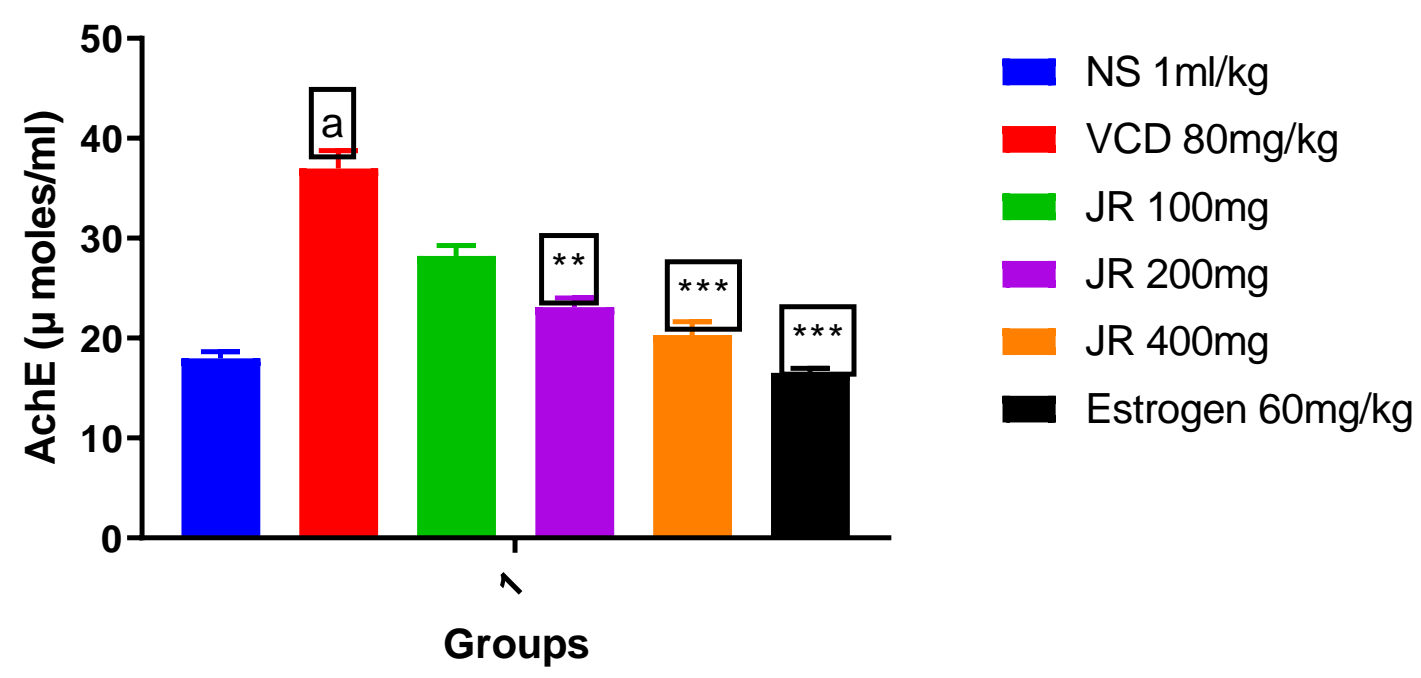

Figure No. 6: Effect of paste of dried kernel of Juglans regia on Acetylcholesterases level in ovotoxicity induced postmenopausal complications in female rats. All values are mean \pm SEM; $N=6$ in group, one way ANOVA followed by Donetts multiple comparison test is applied for statistical analysis. $\mathbf{P}$ values: $* \mathbf{P}<0.05, * * \mathbf{P}<0.01, * * * \mathbf{P}<0.001$ when the results of the treated groups were compared with the control group. When the results of the control group was compared with the normal group.

Index: NS= Normal Saline, VCD= 4-vinyl cyclohaxenediepoxide, $J R=j u g l a n s r e g i a$

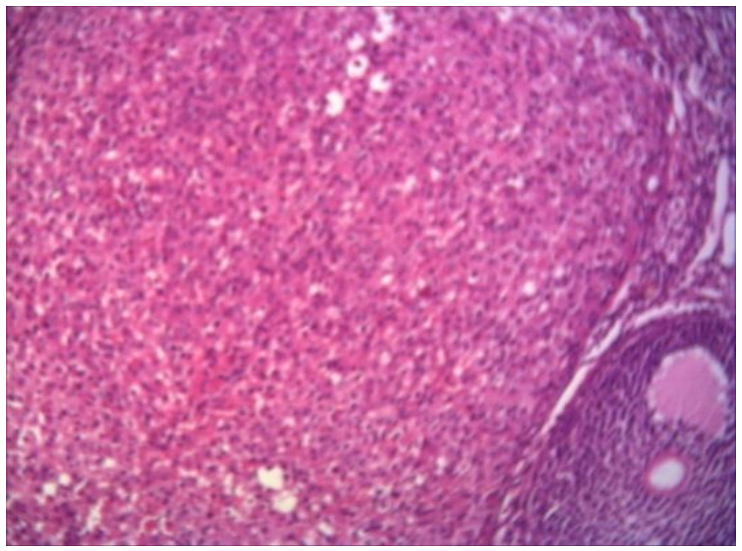

(a)

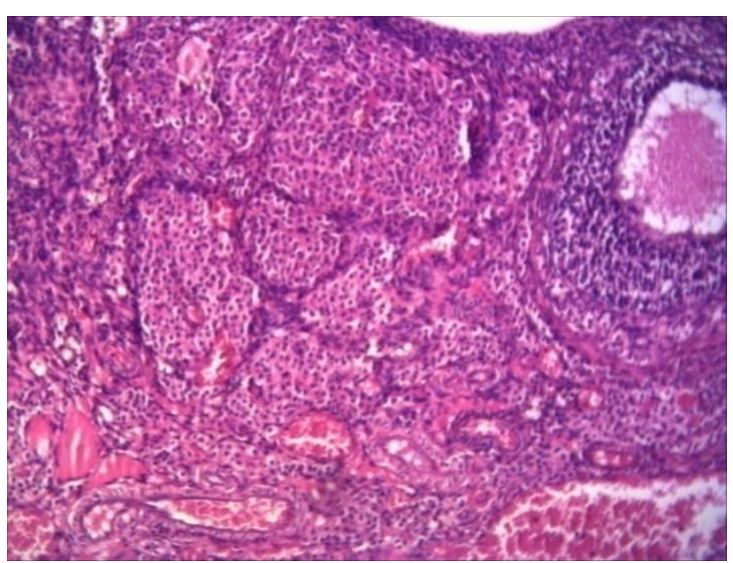

(b) 


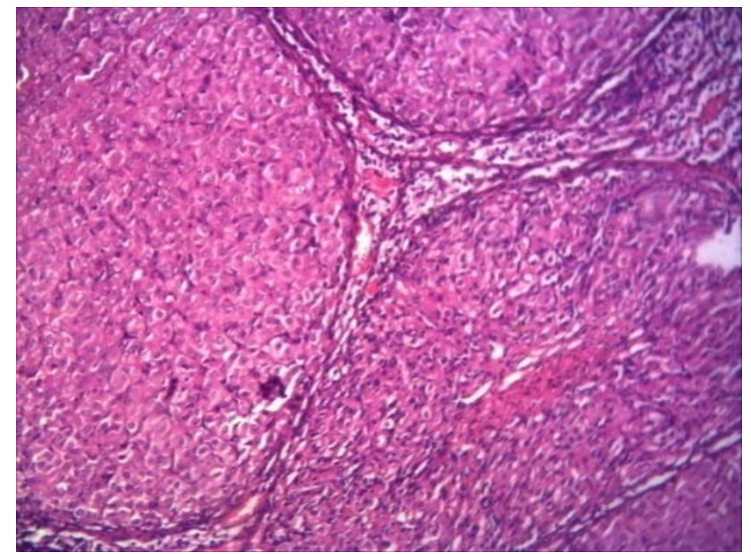

(c)

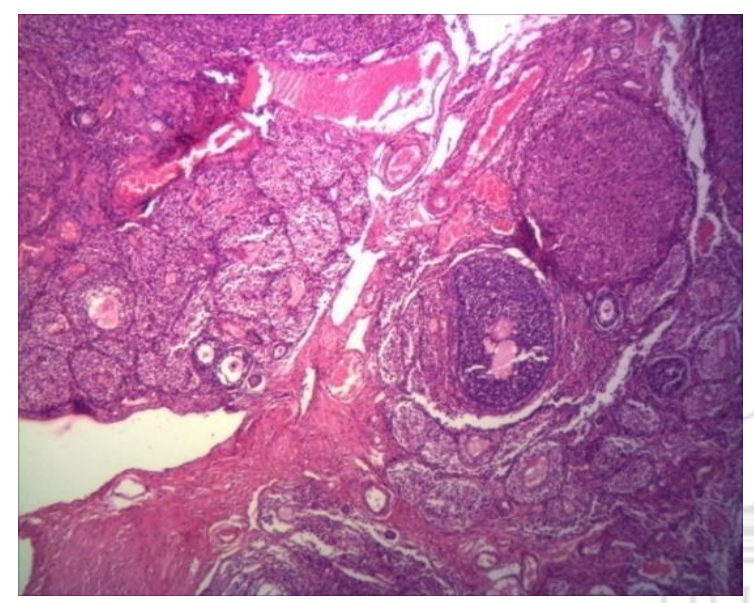

(e)

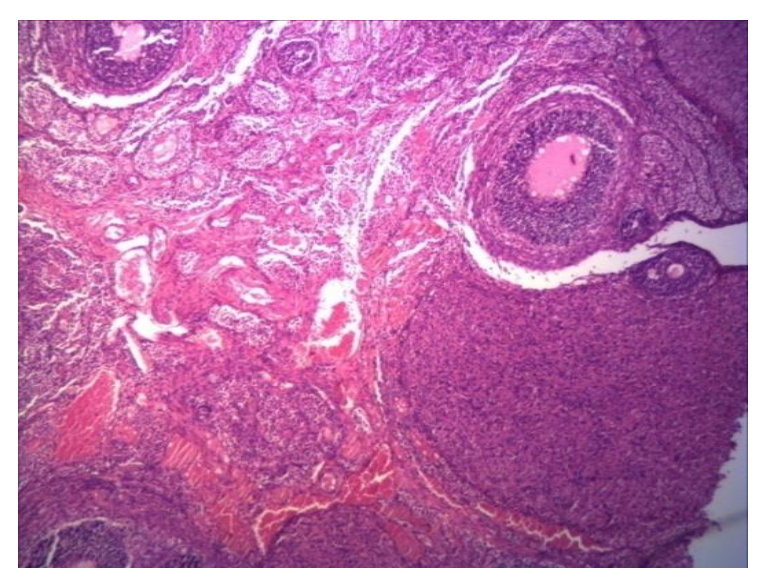

(d)

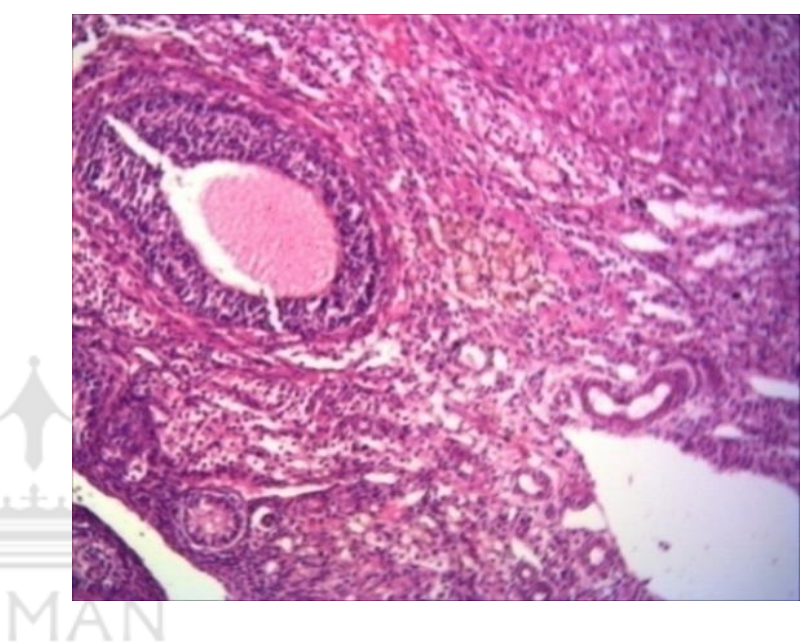

(f)

Figure No. 7: Hematoxylin and eosin staining of ovaries of all groups of animals for evaluating the effect of treatment and VCD on the ovarian follicle and ovarian tissue on original magnification $\times 100$. In which Figure (a) normal group, (b) VCD induced group, (c) paste of $J R$ at $100 \mathrm{mg} / \mathrm{kg}$ administered group, (d) paste of $J R$ at $200 \mathrm{mg} / \mathrm{kg}$ administered group, (e) paste of $J R$ at $400 \mathrm{mg} / \mathrm{kg}$ administered group, (h) estrogen at $60 \mathrm{mg} / \mathrm{kg}$ administered group.

Index: VCD= 4-vinyl cyclohaxenediepoxide, $J R=j u g l a n s r e g i a$ 


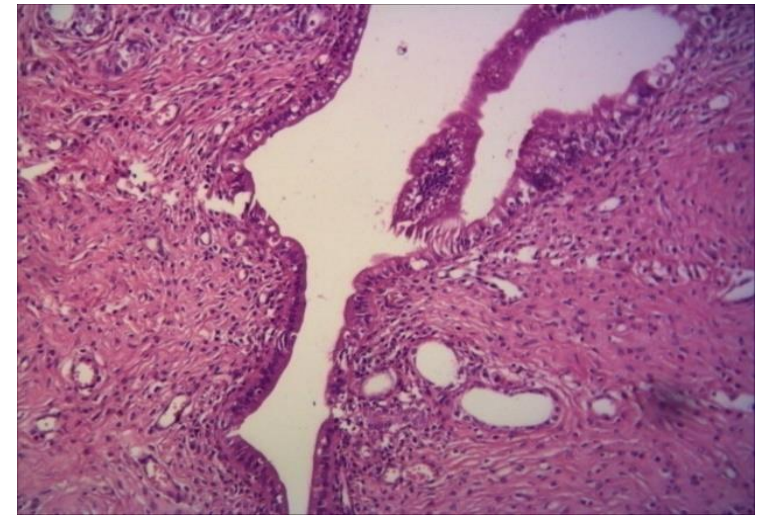

(a)

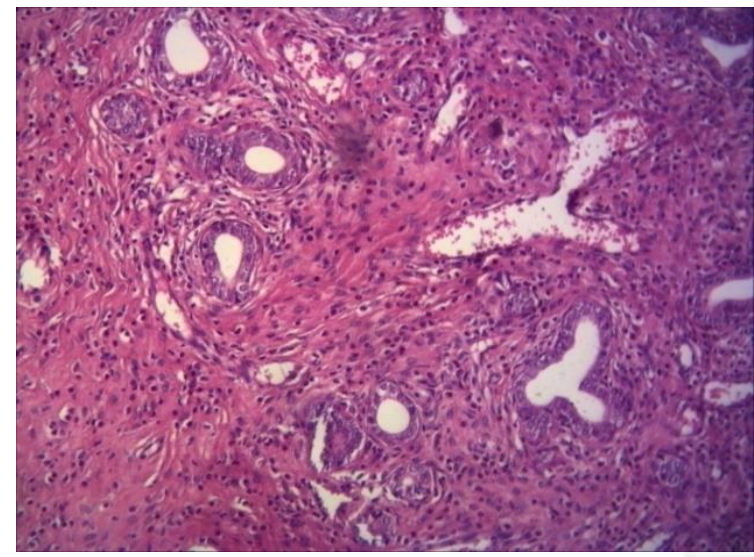

(c)

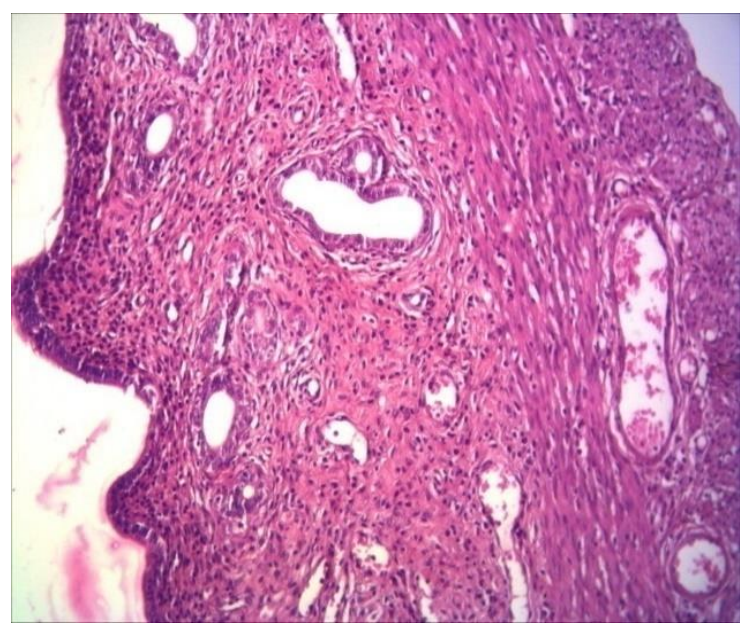

(e)

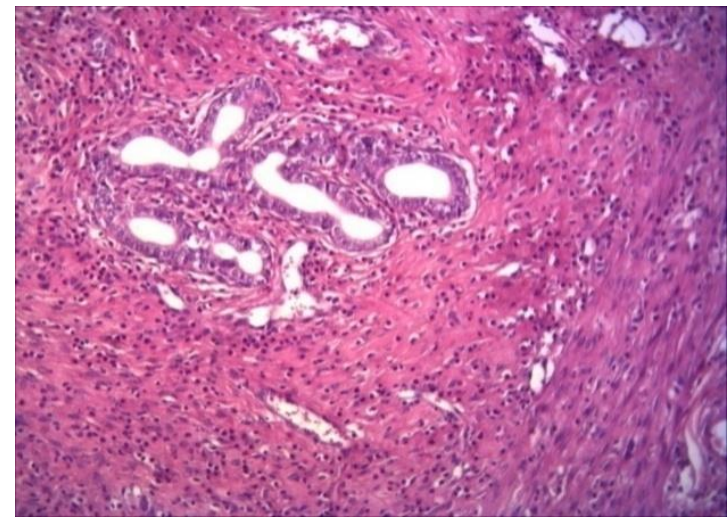

(b)

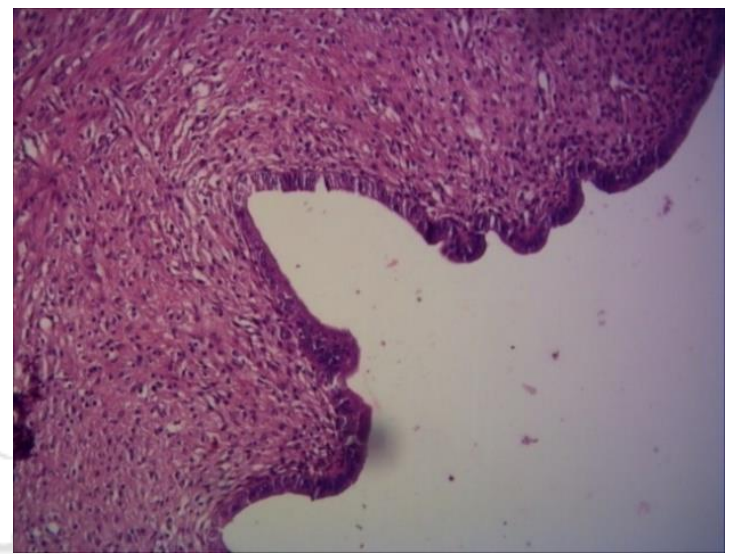

(d)

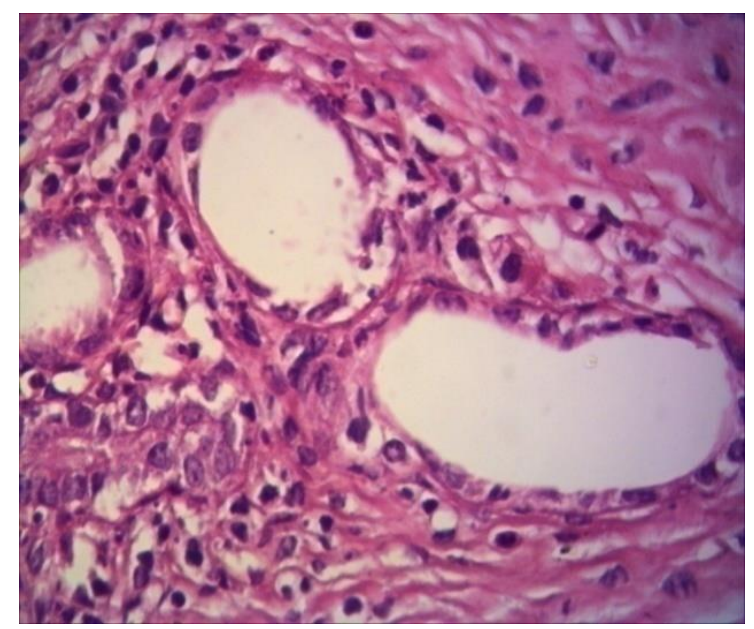

(f)

Figure No. 8: Hematoxylin and eosin staining of uterus of all groups of animals for evaluating the effect of treatment and VCD in endometrium on original magnification $\times 100$. In which Figure (a) normal group, (b) VCD induced group, (c) paste of $J R$ at 100 
www.ijppr.humanjournals.com

$\mathrm{mg} / \mathrm{kg}$ administered group, (d) paste of $J R$ at $200 \mathrm{mg} / \mathrm{kg}$ administered group, (e) paste of $J R$ at $400 \mathrm{mg} / \mathrm{kg}$ administered group, (f) estrogen at $60 \mathrm{mg} / \mathrm{kg}$ administered group.

Index: VCD= 4-vinyl cyclohaxenediepoxide, $J R=j u g l a n s r e g i a$ 